\title{
Where to Next? Research Directions after the First Hepatitis C Vaccine Efficacy Trial
}

\author{
Christopher C. Phelps ${ }^{1}\left(\mathbb{D}\right.$, Christopher M. Walker ${ }^{1,2}$ and Jonathan R. Honegger ${ }^{1,2, *,+} \mathbb{D}$ \\ 1 Center for Vaccines and Immunity, Abigail Wexner Research Institute at Nationwide Children's Hospital, \\ Columbus, OH 43205, USA; Christopher.Phelps@nationwidechildrens.org (C.C.P.); \\ Christopher.Walker@nationwidechildrens.org (C.M.W.) \\ 2 Department of Pediatrics, The Ohio State University College of Medicine, Columbus, OH 43210, USA \\ * Correspondence: jonathan.honegger@nationwidechildrens.org \\ + Current address: Abigail Wexner Research Institute at Nationwide Children's Hospital, 700 Children's Drive, \\ WA4020, Columbus, OH 43205, USA.
}

Citation: Phelps, C.C.; Walker, C.M.; Honegger, J.R. Where to Next? Research Directions after the First Hepatitis C Vaccine Efficacy Trial. Viruses 2021, 13, 1351. https:/ / doi.org/10.3390/v13071351

Academic Editor: Thomas Fuerst

Received: 24 May 2021

Accepted: 8 July 2021

Published: 13 July 2021

Publisher's Note: MDPI stays neutral with regard to jurisdictional claims in published maps and institutional affiliations.

Copyright: (c) 2021 by the authors. Licensee MDPI, Basel, Switzerland. This article is an open access article distributed under the terms and conditions of the Creative Commons Attribution (CC BY) license (https:// creativecommons.org/licenses/by/ $4.0 /)$.

\begin{abstract}
Thirty years after its discovery, the hepatitis $\mathrm{C}$ virus (HCV) remains a leading cause of liver disease worldwide. Given that many countries continue to experience high rates of transmission despite the availability of potent antiviral therapies, an effective vaccine is seen as critical for the elimination of HCV. The recent failure of the first vaccine efficacy trial for the prevention of chronic $\mathrm{HCV}$ confirmed suspicions that this virus will be a challenging vaccine target. Here, we examine the published data from this first efficacy trial along with the earlier clinical and pre-clinical studies of the vaccine candidate and then discuss three key research directions expected to be important in ongoing and future HCV vaccine development. These include the following: 1. design of novel immunogens that generate immune responses to genetically diverse HCV genotypes and subtypes, 2. strategies to elicit broadly neutralizing antibodies against envelope glycoproteins in addition to cytotoxic and helper $\mathrm{T}$ cell responses, and 3. consideration of the unique immunological status of individuals most at risk for $\mathrm{HCV}$ infection, including those who inject drugs, in vaccine platform development and early immunogenicity trials.
\end{abstract}

Keywords: hepatitis C virus (HCV); vaccine; immunity; T cells; B cells; antibodies; chronic infection; clinical trial

\section{The Ongoing Need for a Vaccine}

Thirty years ago, the discovery of the small, positive-stranded RNA virus responsible for hepatitis $\mathrm{C}$ provided the means to halt disease transmission by blood transfusion and fostered optimism that a vaccine may soon follow [1]. To date, however, no vaccine is available, and the hepatitis $\mathrm{C}$ virus ( $\mathrm{HCV}$ ) remains a major global public health concern [2] An estimated 71 million people are currently infected, and nearly 400,000 individuals die each year due to HCV-associated liver fibrosis and carcinoma [2,3]. New infections continue to occur at a high rate, with an estimated 1.7 million occurring in 2015 [3].

More recently, approval of breakthrough oral direct-acting antiviral (DAA) therapies capable of curing over $95 \%$ of chronic HCV infections of any genotype has kindled hope that the global HCV pandemic might be ended through treatment [4]. This led the WHO, in 2016 , to set a goal to eliminate HCV as a global public health problem by 2030, specifically by treating $80 \%$ of those infected and reducing new infections by $90 \%$ [5]. However, the incidence of $\mathrm{HCV}$ infections has continued to rise in many countries since the introduction of DAAs. In the US, rates of reported and estimated acute infections nearly doubled in the 5 years following the first approval of interferon-free DAA regimens in 2013 [6]. Challenges to HCV elimination by treatment include (1) failure to recognize most infections due to lack of overt symptoms and deficient screening of those at risk [7], (2) increasing difficulty reaching vulnerable populations after initial waves of treatment in the "easiest" 
patients already engaged in healthcare [8], (3) high costs of widespread screening and treatment [9], (4) emergence of viral resistance [10,11], and (5) importantly, re-infections following antiviral cure among individuals with ongoing exposure [12]. For these reasons, a prophylactic vaccine is urgently needed to complement ongoing treatment programs in order to meet the imperative to eliminate the global public health burden of HCV [13,14].

\section{HCV Vaccine Feasibility and Development}

$\mathrm{HCV}$ is recognized as a challenging vaccine target due to its vast genetic diversity and propensity to evade immunity, but several features of its natural history suggest that vaccination may be feasible. First, because the major health complications of HCV such as cirrhosis or hepatocellular carcinoma arise only after years of persistent viremia [15], a successful $\mathrm{HCV}$ vaccine would not necessarily be required to prevent infection. Rather, it must induce immune memory responses capable of clearing infection prior to the onset of adverse outcomes. Second, $20-30 \%$ of infected individuals spontaneously resolve viremia in the first 6-12 months, and, if reinfected, these individuals rapidly clear viremia in $80 \%$ of cases [16]. This supports the notion that induction of protective adaptive immune memory is possible.

These observations have spurred intensive efforts to identify immune mechanisms of natural viral clearance that might guide vaccine design. Numerous lines of evidence point to a central role of cellular immunity in controlling HCV infection. In acute HCV infection, after a 4-12 week incubation period of high-level viral replication, the appearance of highly functional and broadly reactive $\mathrm{CD} 4^{+} \mathrm{T}$ helper cells $[17,18]$ and $\mathrm{CD} 8^{+}$cytotoxic $\mathrm{T}$ cells [19-21] targeting primarily nonstructural proteins of HCV (NS3-NS5) in the peripheral blood correlates with rapid reductions in viral load in subjects that go on to resolve infection $[22,23]$. Depletion of either $\mathrm{CD}^{+}$or $\mathrm{CD}^{+}$cells in a chimpanzee model of reinfection demonstrated that both populations are required for viral clearance [24,25]. Similar initial responses may be detected early in persisting infections, but HCV-specific $\mathrm{CD} 4^{+} \mathrm{T}$ cell populations soon decline and become nearly undetectable $[17,26]$. This lack of $\mathrm{CD} 4^{+} \mathrm{T}$ cell help is thought to contribute to an impaired HCV-specific CD8 ${ }^{+} \mathrm{T}$ cell response [24] with reduced cytokine production, cytotoxicity, and proliferative capacity seen in humans with chronic infection $[27,28]$.

The role of humoral immunity in controlling HCV infection has been less clear. Early evidence of viral clearance in seronegative patients and those with agammaglobulinemia, as well as lack of correlation of development of neutralizing antibodies with viral clearance, suggested that antibody responses may be dispensable and of limited value for resolution of infection [29-33]. On the other hand, passive administration of neutralizing antibodies could prevent infection in mouse and chimpanzee models [34-36]. Moreover, active vaccination of chimpanzees with envelope glycoproteins to induce humoral responses, while not necessarily resulting in sterilizing immunity, was protective against chronic infection [37,38]. More recent studies found that spontaneous clearance in humans is associated with the early development of antibodies capable of neutralizing autologous circulating viral strains or libraries of viral strains [39,40].

Reflecting the emerging understanding of natural immunity to HCV, vaccine development has taken two primary and divergent approaches, attempting to either elicit T-cell responses, usually targeting non-structural viral proteins, or induce neutralizing antibodies against viral envelope glycoproteins. Platforms being evaluated in pre-clinical studies include traditional technologies, such as recombinant proteins, synthetic peptides, and virus-like particles often aimed at eliciting antibody responses, and emerging technologies, including genetic vaccines (both DNA and mRNA) and viral vector vaccine approaches designed to elicit T-cell responses [41]. Whole virus vaccines, either inactivated or liveattenuated, have until recently not been pursued due to limitations of HCV cell culture and, in the latter case, safety precautions [42].

Several major bottlenecks have hindered the progression of $\mathrm{HCV}$ vaccine candidates from pre-clinical studies to human efficacy trials. First, the only immunocompetent ex- 
perimental animal model of $\mathrm{HCV}$ recapitulating both acute and chronic infection was the chimpanzee, which precluded large challenge studies and is no longer available [43]. This limitation may be partially mitigated by the recent discovery of animal hepaciviruses closely related to HCV. An immunocompetent rat hepacivirus model has been developed, though its ability to predict protection for HCV remains unknown [44]. Second, there exists no established immune correlate of protection against chronic HCV infection to guide the transition from human immunogenicity to efficacy studies [45]. Finally, studies in human populations most at risk for $\mathrm{HCV}$, primarily people who inject drugs (PWID), are logistically difficult and possible only in a small number of specialized cohorts with sophisticated infrastructure for subject retention and care [46,47].

We will herein review the recently published results of the first efficacy trial of an $\mathrm{HCV}$ vaccine [48]. This landmark trial tested a promising approach employing viral vectors to encode nonstructural $\mathrm{HCV}$ proteins known to generate robust $\mathrm{HCV}$-specific T-cell responses in healthy adults. While this trial, conducted in a cohort of at-risk individuals, confirmed immunogenicity in most vaccine recipients, the immune response elicited was seemingly insufficient to prevent chronic HCV infection. Here, we review the design and results of this study, speculate on potential reasons this vaccine candidate may have failed to protect at-risk individuals, and consider important questions to be addressed by future studies. Given the immense barriers that limit opportunities to transition from pre-clinical to efficacy trials in this field, it will be essential to glean as much direction as possible from this trial to inform future studies.

\section{The Adenovirus/MVA HCV Vaccine Efficacy Trial}

In 2019, the preliminary results from the first human efficacy trial of an HCV vaccine were made publicly available, and full results were published in early 2021 [48]. Conducted from 2012-2018 among at-risk PWID at three sites across the United States (ClinicalTrials.gov NCT01436357), this randomized, double-blinded, placebo-controlled (1:1), phase I/II study assessed the safety and efficacy of an immunization strategy that delivered genes encoding non-structural $\mathrm{HCV}$ proteins within viral vector constructs. The primary inoculation used a replication-incompetent recombinant chimpanzee adenovirus 3 (ChAd3) vector encoding NS3-NS5B from a natural genotype $1 \mathrm{~b}$ HCV strain (ChAd3-NSmut1). The booster dose administered 8 weeks later used a modified vaccinia Ankara (MVA) vector expressing the same NS3-NS5B gene cassette (MVA-NSmut). The trial followed 548 volunteers for 20 months ( 2 months for vaccination and 18 months for follow-up) with an additional 9 months of observation for volunteers who became infected with HCV to distinguish chronic vs. acute resolving outcomes. The primary outcome measure was development of chronic $\mathrm{HCV}$ infection, defined as persistent viremia 6 months after initial detection. Complete follow-up was achieved for 152 of $274(55.4 \%)$ volunteers in the experimental arm and 146 of $274(53.2 \%)$ in the placebo arm. Ultimately, 5.1\% of participants in both the vaccinated group $(n=14)$ and the placebo group $(n=14)$ developed chronic HCV infection, indicating that immune responses elicited by the vaccine were unable to prevent the establishment of persistent viremia.

These disappointing results were not readily predicted from earlier studies. The use of replication-incompetent adenoviral vectors carrying genes encoding for HCV antigens was supported by a substantial body of pre-clinical and clinical research showing the capacity to generate $\mathrm{CD}^{+}$and $\mathrm{CD}^{+} \mathrm{T}$ cell responses to $\mathrm{HCV}$ thought to be similar to those associated with spontaneous control. The approach was shown to be promising in a chimpanzee challenge model by Capone, Folgori, and colleagues in 2006 [49]. The immunization strategy utilized adenovirus type 6 (Ad6) and adenovirus type 24 (Ad24) vectored constructs expressing NS3-NS5B genes of a natural genotype $1 \mathrm{~b}$ HCV strain with a mutation designed to eliminate NS5B polymerase activity (NSmut), followed by serial doses of plasmid DNA containing the same NS3-NS5b cassette [50]. In a study of vaccinated chimpanzees, $\mathrm{HCV}$-specific $\mathrm{CD} 4^{+}$and $\mathrm{CD}^{+} \mathrm{T}$ cells that produced IFN- $\gamma$ and proliferated after antigen stimulation were detected. Cytotoxic $\mathrm{CD} 8^{+} \mathrm{T}$ cell responses were also detected 
in four of five animals [49]. Subsequent challenge with a heterologous genotype 1a HCV resulted in significantly reduced viremia and rapid viral clearance in four of five animals when compared to control animals [49]. Further development efforts included screening a large number adenoviral strains to identify candidates that readily infect human cells, are highly immunogenic, and yet rare in humans and thus unlikely to be inhibited by pre-existing immunity [51]. These efforts identified chimpanzee adenovirus 3 (ChAd3) as a promising vector candidate. Human studies in healthy volunteers primed with the ChAd3 vector determined that boosting with modified vaccinia Ankara (MVA) vectored construct resulted in superior $\mathrm{CD}^{+}$and $\mathrm{CD}^{+} \mathrm{HCV}$-specific $\mathrm{T}$ cell responses than did boosting with a second adenoviral construct (Ad6) [52,53]. In phase I trials, all recipients of the ChAd3NSmut1/MVA-NSmut regimen developed T cell responses against all nonstructural HCV proteins from genotype $1 \mathrm{~b}$ viruses. $\mathrm{CD} 4^{+}$and $\mathrm{CD} 8^{+} \mathrm{T}$ cells produced IFN- $\gamma, \mathrm{TNF} \alpha$, or IL-2, with many being multi-functional. Using an MHC-class I pentamer, the majority of $\mathrm{HCV}$ specific $\mathrm{CD}^{+} \mathrm{T}$ cells were found to have a CD45RA-CCR7 ${ }^{-}$effector memory phenotype at the end of the study [53]. A degree of T-cell cross-reactivity was demonstrated to nongenotype $1 \mathrm{~b}$ peptides, though the response frequency was lower for subtype $1 \mathrm{a}$ peptides than $1 \mathrm{~b}$, and markedly reduced for distinct genotypes $3 \mathrm{a}$ and $4 \mathrm{a}$. Nonetheless, the data were encouraging enough to move the vaccine to phase II efficacy trials.

The lack of efficacy against chronic HCV infection in the phase II trial, despite the promising data from the earlier phase I trial, is perplexing. In the phase II trial, immunogenicity was evaluated within 14 days after the last vaccination by ELISpot, when possible. Of the experimental group participants tested, $77.6 \%$ developed measurable IFN- $\gamma$ producing $\mathrm{T}$ cells targeting at least one of six HCV genotype $1 \mathrm{~b}$ peptide pools [48]. Detailed analyses of the strength, breadth, polyfunctionality, phenotype, and durability of these responses in this larger cohort have not yet been published. Likewise, no information is available regarding $\mathrm{T}$ cell cross-reactivity against heterologous viral genotypes. More in-depth analysis of samples from this trial could provide important insight into why this vaccine strategy was ineffective and how future approaches may be adjusted to optimize opportunities for success.

Until additional detailed studies can be conducted, there are still potential insights to be gained from the data available. In the following sections, we consider factors that may, at least in part, help to explain the failure of this vaccine to protect against chronic $\mathrm{HCV}$ despite promising immunogenicity, and explore three questions that should be addressed in future vaccine research efforts.

1. Must an HCV vaccine better address HCV genetic diversity? The vast genetic diversity of HCV has long been recognized as a challenge for vaccine development. While it was hoped that a vaccine based on a single viral genotype could generate protective cross-reactive responses against a wide variety of genotypes, successful vaccines may require more directed efforts to represent viral antigenic diversity.

2. Does an HCV vaccine need to elicit neutralizing antibodies? While it is established that a robust cell-mediated immune response targeting primarily non-structural HCV proteins is strongly linked with spontaneous control, mounting evidence also supports an important role of neutralizing antibodies targeting HCV envelope proteins. Strategies to induce broadly neutralizing antibodies against diverse viral populations continue to advance. A successful vaccine may require the incorporation of both structural and non-structural protein targets to elicit robust neutralizing antibodies and $\mathrm{T}$ cell responses that cooperatively avert chronic HCV infection.

3. Do factors unique to populations at risk for HCV need to be considered in early immunogenicity trials? Injection drug use is the primary risk factor for HCV acquisition in high-income nations, and PWID are prime candidates for any successful prophylactic HCV vaccine, if approved. Accordingly, active injection drug use was among the inclusion criteria in the ChAd3/MVA-NSmut vaccine efficacy trial. Several factors exist by which immunity and response to vaccination may be altered in PWID, 
including opiate use and repeated sub-infectious HCV exposure. These factors need to be considered in future $\mathrm{HCV}$ vaccine development and trial design.

Finally, though DAA therapy has revolutionized the management of chronic HCV, treated patients do not develop protective immunity after cure and remain vulnerable to reinfection if re-exposed. These individuals will also be important candidates for $\mathrm{HCV}$ vaccination. A better understanding of the residual immune defects following cure of chronic HCV infection and how or if new vaccine platforms can overcome this damage to establish protective immunity will be of critical importance for the ultimate elimination of $\mathrm{HCV}$.

\section{Addressing Genotypic Cross-Reactivity of T Cells}

The genetic diversity of HCV exceeds even that of HIV [54,55]. HCV isolates are classified into seven major genotypes and over 90 subtypes. Variability at the nucleic acid level reaches up to $30 \%$ between genotypes [56]. While the resolution of infection with one genotype can protect against other genotypes [57], this protection is not absolute [58-60]. Indeed, $\mathrm{T}$ cells arising during infection target viral epitopes that tend to be genotype- and even subtype-specific. Within a cohort of individuals infected with genotype $3 \mathrm{HCV}$, very few genotype 1 cross-reactive epitopes were identified [61].

Whether a lack of $\mathrm{T}$ cell cross-reactivity contributed to the failure of the genotype $1 \mathrm{~b}$ ChAd3/MVA-NSmut vaccine to prevent chronic HCV is at this time unknown. In secondary analysis, the vaccine lacked signal of protective efficacy for both genotype 1 and non-genotype 1 infections, precluding any meaningful comparison of cross-genotype protection [48]. IFN- $\gamma$ ELISpot responses to genotype $1 \mathrm{~b}$ peptide pools were detected in approximately three-quarters of vaccinated individuals, but responses to other viral genotypes have not been assessed [48]. Likewise, viral sequence data have not yet been assessed to determine the relatedness of infecting and vaccine sequences at relevant $\mathrm{CD} 8^{+}$ and $\mathrm{CD} 4^{+} \mathrm{T}$ cell epitopes.

Assessments of cross-reactivity of $\mathrm{T}$ cell responses elicited by the genotype $1 \mathrm{~b}$ ChAd3/MVA-NSmut vaccine are available from phase I immunogenicity trials in healthy control subjects. Indeed, cross-reactive IFN- $\gamma$ ELISpot responses were detected against peptide pools from heterologous genotypes, but with reduced frequency. Compared to the robust responses to genotype $1 \mathrm{~b}$ peptides, $\mathrm{T}$ cell reactivity was reduced by approximately $40 \%$ against closely related subtype 1a peptides, and by $70 \%$ against more divergent genotypes 3a and 4a [53]. Whether these responses would be sufficient to protect against persistent infection upon heterologous virus challenge is unknown [53]. Despite remaining uncertainties as to whether deficient cross-reactivity contributed to the failure of the ChAd3/MVA-NSmut vaccine phase II trial, it is reasonable to expect that future vaccine iterations should incorporate antigen designs that generate more broadly reactive responses across genotypes.

Numerous vaccine approaches to the challenge of viral diversity are being evaluated for HCV and other viruses including HIV. One such approach aims to specifically target regions of the virus that are conserved across multiple viral clades or genotypes by stitching together conserved regions and excluding highly diverse regions of the viral proteome. This has been pioneered in the development of new HIV vaccine candidates. In the case of

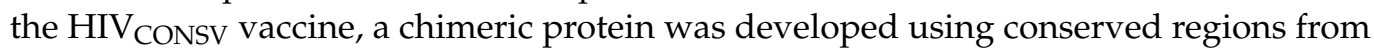
HIV-1 clades A, B, C, and D with the goal of developing T cell responses to epitopes that are more likely to be shared among a multitude of strains [62]. The HIV CONSV regions appear to be widely targeted in individuals with natural HIV infection, though, interestingly, the responses to the conserved epitopes commonly represent subdominant $\mathrm{T}$ cell responses [62]. This construct has been shown to be immunogenic in uninfected mice [62], macaques [63], and humans $[64,65]$. While using this approach has shown only partial protection in macaques to date [66], the data have been promising and efforts to apply a similar approach in novel HCV vaccines are underway $[67,68]$. Rather than use conserved genetic regions from various $\mathrm{HCV}$ genotypes, von Delft and colleagues used circulating HCV isolates 
that had the highest homology to the consensus sequences of conserved genetic regions in each group of viral isolates of interest (genotypes $1 \mathrm{a} / \mathrm{b}$, genotypes $1 / 3$, and genotypes $1-6)$ as a starting point. The group then stitched together conserved regions and removed the variable regions. This yielded three new vaccine vectors for targeting different sets of HCV genotypes, including one vector meant to target all but genotype 7 viruses, dubbed GT1-6L [67]. Initial tests of GT1-6L, encoded in a chimpanzee adenovirus ChAdOx1, demonstrated immunogenicity in mice. ELISpot assays also showed that GT1-6L elicited T cell response to peptides from genotype $1 \mathrm{a}, 1 \mathrm{~b}$, and $3 \mathrm{a}$ viruses at similar levels [67]. Further study demonstrated that immunization of mice with ChAdOx1-GT1-6L induced both a higher magnitude and wider breadth of $\mathrm{T}$ cell responses against genotype $1 \mathrm{~b}$ peptide pools when compared to ChAdOx1-GT1b-NS, a control vaccine based on the previous first-generation vaccine [68]. GT1-6L also elicited better T cell responses in terms of both magnitude, when splenocytes were stimulated with genotype 3a peptides, and breadth, when stimulated with genotype 1a peptides [68]. While safety and immunogenicity results in non-human primates and humans are not yet available, the current data suggest that this approach to generating pan-genotypic T cell responses is promising.

A separate approach to minimize sequence dissimilarity between a candidate $\mathrm{HCV}$ vaccine antigen and contemporary circulating HCV strains is the rational design of Mosaic or Epigraph antigens. Mosaic and epigraph antigens are designed computationally by recombination of viral genomic sequences retrieved from databases, with the requirement that all recombination breakpoints exist in natural HCV sequences, precluding the creation of artificial junctional epitopes [69-71]. Viral diversity is overcome in two ways. First, less common amino acids are disfavored at each position of the antigen, reducing the probability of vaccine- or strain-specific $T$ cell responses, while common amino acids are favored to maximize the most common potential $T$ cell epitopes [69-71]. Second, these vaccines are typically polyvalent to further expand the breadth of epitope and maximize sequence diversity. Importantly, mosaics and epigraphs are indistinguishable from natural viral proteins in sequence and processing for class I and class II presentation. Mosaic design is the most advanced for HIV vaccines [72]. In macaques, HIV-1 mosaics induced significantly higher numbers of cross-reactive $\mathrm{CD}^{+}$and $\mathrm{CD}^{+} \mathrm{T}$ cells than natural protein vaccines $[73,74]$. Vaccinated animals were also more difficult to infect and did not succumb to infection when compared to unvaccinated macaques [75]. Mosaic HIV vaccines have demonstrated immunogenicity in humans [76,77], suggesting potential for translation to an $\mathrm{HCV}$ vaccine. The feasibility of mosaic design of a pan-genotypic HCV vaccine has been demonstrated by in silico analysis, with multivalent mosaic antigens providing the best coverage against diverse $\mathrm{HCV}$ isolate sequences [54]. Immunization experiments further demonstrated the immunogenicity of mosaic HCV vaccines in mice and found that they induced more robust responses than immunization with antigens from natural viral strains [78]. Further iterations on the HCV mosaic/epigraph vaccine platform involving the incorporation of different delivery platforms, new adjuvants, and boosting strategies, and further murine studies will be required before transitioning to non-human primates for continued safety and immunogenicity studies.

While both the conserved-region vaccine and mosaic/epigraph vaccine approaches offer their own advantages and have promise individually, using a combination of methods may yield the most effective result. Indeed, in the field of HIV, a new generation of $\mathrm{HIV}_{\mathrm{CONSV}}$ vaccines, $\mathrm{HIV}_{\mathrm{CONSV}} \mathrm{X}$, has been introduced. These second-generation vaccines incorporate both the use of conserved regions and computationally developed Mosaic approaches in a multivalent vaccine, and they have been shown to be highly immunogenic [79], with some components being currently evaluated in phase I clinical trials (NCT03844386). Because circulating HCV may demonstrate wider variability than HIV, similarly multi-pronged approaches to developing a $\mathrm{T}$ cell-focused $\mathrm{HCV}$ vaccine may also prove necessary. 


\section{Harnessing Neutralizing Antibody Responses in New Vaccines}

While multiple lines of evidence support a central role of $\mathrm{CD}^{+}$and $\mathrm{CD} 4^{+} \mathrm{T}$ cells in the control of $\mathrm{HCV}$ infection, the role of antibodies in resolving infection and, by extension, their potential protective value in vaccine-elicited responses, has been less clear. Documented cases of HCV clearance in seronegative PWID and in patients with agammaglobulinemia [29-31] indicated that antibodies may be dispensable. To address whether humoral responses may yet contribute to viral clearance in some patients, multiple studies have attempted to identify correlations between infection outcome and the development of antibodies, particularly neutralizing antibodies that target the HCV envelope glycoprotein heterodimer responsible for viral attachment and entry, E1/E2. Early studies that measured neutralization of lentiviral pseudoparticles expressing HCV E1E2 glycoproteins (HCVpp) from prototypical HCV strains such as $\mathrm{H} 77$ found high titer serum neutralizing antibodies during the chronic phase of infection and absent or rare antibodies in early infection that did not associate with viral clearance [32,33]. In contrast, several studies that used HCVpp bearing autologous E1E2 sequences found viral clearance to be associated with rapid induction of neutralizing antibodies against the transmitted or early circulating viral strain [39,80-82]. A study using a library of HCVpp with representative E1E2 sequences linked spontaneous viral clearance with the early development of broadly neutralizing antibodies [40]. Moreover, E2-specific memory B cells have been found to expand and peak more rapidly in resolvers than those who progress to chronic infection. This rapid expansion is associated with more robust early activity of circulating IL-21 producing T follicular helper (Tfh) cell populations [83]. Thus, an increasing preponderance of evidence suggests that the rapid development of specific and broadly neutralizing antibodies in acute infection may contribute to viral clearance.

Although this understanding of the role of antibodies in HCV infection outcome has taken some time to come into view, neutralizing antibodies have been a focus of $\mathrm{HCV}$ vaccine development efforts from the outset given their importance in vaccination strategies against other viral infections [38]. An early construct consisting of purified recombinant $\mathrm{HCV}$ genotype 1a (strain $\mathrm{HCV}-1$ ) E1E2 protein administered to chimpanzees with an oil/water emulsion adjuvant elicited E1E2 antibodies that in some cases appeared to confer sterilizing immunity upon challenge with homologous virus HCV-1 virus [37] and protected against chronic infection upon challenge with a heterologous genotype 1a H77 strain [38]. The overall rate of chronic infection in 31 E1E2 vaccinated chimpanzees challenged with genotype 1a viruses was $16 \%$, compared to $63 \%$ in 24 unimmunized controls [38,84]. Serum from E1E2-vaccinated chimpanzees exhibited cross-neutralization of HCVpp or cell-cultured HCV (HCVcc) expressing envelope proteins of other genotype 1 a viruses as well as genotypes 4,5 , and 6 , but had little activity against genotypes 2 or 3 [85]. Given the promising pre-clinical data, the recombinant HCV-1 E1E2 construct adjuvanted with MF59 proceeded to phase I trials in healthy volunteers [86]. The vaccine was well-tolerated and reliably elicited high titers of E1E2-binding antibodies and robust proliferative $\mathrm{CD}^{+} \mathrm{T}$ helper responses [86]. Serum from most vaccinees could interfere with E2 binding to the CD81 receptor and neutralize HCVpp or HCVcc expressing autologous HCV-1 E1E2 [86,87] but rarely had broad cross-genotype neutralization activity $[87,88]$.

Follow-up studies found the most dominant responses elicited by E1E2 vaccination targeted the N-terminus of E1 and the hypervariable region 1 (HVR1) at the N-terminus of E2 and were mostly non-neutralizing [87]. Neutralizing antibodies were raised against HVR1 as well as conserved sites associated with the potential for broad cross-reactivity such as the antigenic region 3 (AR3) located on the "neutralization face" of E2 that overlaps the CD81 binding site [87]. AR3-specific broadly neutralizing antibodies have been associated with $\mathrm{HCV}$ clearance and commonly utilize a particular immunoglobulin heavy-chain-variable gene $V_{H} 1-69$ [89-91]. These AR3-specific $V_{H} 1$-69-encoded broadly neutralizing antibodies often have quite limited somatic hypermutation, suggesting that a germ-line targeting vaccine approach to elicit this desirable response may be feasible [92]. E1E2 immunized rhesus macaques also generated AR3-neutralizing antibodies that had limited somatic 
hypermutation. These utilized a heavy chain variable gene $V_{H} 1-36$ that is homologous to human $V_{H} 1-69$, potentially providing a pre-clinical model for germline-targeting vaccine strategies $[87,92]$.

Together, studies of the recombinant HCV-1 E1E2 vaccines provide a solid basis for the pursuit of an antibody vaccine, while highlighting the need for optimization to better elicit robust neutralizing responses against conserved regions of the envelope glycoprotein. As such, significant effort has been made to engineer a rational antibody vaccine for $\mathrm{HCV}$, as recently reviewed in detail by several groups [93-95]. These efforts follow insights gained from crystal structures of antibody-bound constructs of truncated E2, improved modeling of the E1E2 heterodimer, and expanded mapping of neutralizing and non-neutralizing antibody binding sites on E1E2. One proposed approach has been to delete highly variable regions such as HVR1, which are purported to act as immunodominant decoy antigens, readily evading strain-specific antibodies by mutational escape while simultaneously interfering with responses to more conserved regions [96-100]. Deletion of HVR1 from adjuvanted E1E2 vaccine reduced the development of homologous strain-specific neutralizing antibodies while also failing to enhance heterologous responses in mice [101]. However, deletion of HVR1 along with other variable regions including HVR2 and VR3 from core E2 structures led to a stabilized E2 structure with preserved "neutralizing face" [102,103] that, when delivered in oligomeric form, induced robust pan-genotypic neutralizing response in guinea pigs and fewer non-neutralizing antibodies [104]. Analogous E2 constructs lacking HVR1 and VR3 with a modified VR2 and incorporated into nanoparticles also elicited robust pan-genotypic responses in rodents [105]. Beyond shielding by the immunodominant HVR1 region, conserved epitopes have been shown to be shielded from immune recognition by glycosylation across E1 and E2 [106-108]. Removal of select glycosylation sites from E1E2 immunogens has been shown to improve the production of neutralizing antibodies and to enhance cell-mediated responses [109,110]. Manipulation of E2 glycosylation by expression in non-mammalian cells may also accentuate immunity to conserved neutralizing epitopes [111]. Finally, beyond uncovering conserved sites, mosaic E1E2 immunogens may also present an approach to the diversity of HCV envelope antigens. While current efforts in the development and testing of mosaic HIV vaccines focus on cell-mediated immunity, they also elicit neutralizing antibodies that target the variable envelope protein of HIV $[69,73,77]$. Immunization with a mosaic HCV E2 immunogen has shown enhanced immunogenicity in mice, though neutralizing antibodies were not specifically studied [78].

\section{New Vaccine Delivery Platforms and a Unified Approach to Target T Cell and B Cell Responses}

A vaccine regimen that elicits both broadly neutralizing antibodies and potent broad $\mathrm{CD}^{+}$and $\mathrm{CD}^{+} \mathrm{T}$ cell responses may have the best odds of preventing chronic $\mathrm{HCV}$ infection. While this seems an obvious vaccine objective, design of such a vaccine requires consideration of both antigen selection and delivery platform. E1E2 or E2 alone is the required immunogen for generation of neutralizing B cell responses, but non-structural proteins may be better immunogens for $\mathrm{T}$ cell responses, as they are more commonly targeted by T cells in natural infection and more conserved (e.g., NS3 and NS5B) than envelope glycoproteins [112]. In terms of vaccine platforms, recombinant protein antigens are well-suited for induction of B cell responses with follicular CD4 T cell help, while intracellular expression and processing of vaccine proteins such as with viral-vectored or DNA vaccine platforms is optimal for MHC I loading to induce $\mathrm{CD}^{+} \mathrm{T}$ cell responses. Thus, one approach would be a regimen combining two different vaccines, one with an envelope protein immunogen in a platform for B cells, and a second with a non-structural protein immunogen delivered in a platform for optimal $\mathrm{CD}^{+} \mathrm{T}$ cell responses. Alternatively, advances in vaccine adjuvant, immunopotentiator, and vaccine particle development offer the potential to trigger multiple immune pathways with a single vaccine platform, such as recombinant protein antigens that with certain adjuvants not only trigger robust $B$ cell and $\mathrm{CD} 4^{+} \mathrm{T}$ cell responses but also induce cross-presentation to $\mathrm{CD} 8^{+} \mathrm{T}$ cells. Numerous 
such platforms are being actively evaluated in pre-clinical and limited clinical studies of new HCV vaccines, and recent reviews have examined this in more comprehensive detail $[113,114]$.

The recent success of mRNA vaccines encapsulated in lipid nanoparticles (LNPs) for SARS-CoV-2 $[115,116]$ raises another intriguing option for an HCV vaccine that might induce protective antibody and T cell responses. The BNT162b2 and mRNA-1273 SARS$\mathrm{CoV}-2$ vaccines both encode a full-length, pre-fusion stabilized SARS-CoV-2 spike protein and are aimed at eliciting neutralizing antibodies that prevent interactions between the viral spike protein and the cellular receptor ACE2 [117,118]. Both vaccines elicit high neutralizing anti-spike antibody titers as well as polyfunctional antigen-specific $\mathrm{CD}^{+}$ $\mathrm{T}$ cells with a significant skew towards Th1 responses and away from Th2 responses in humans and non-human primates [117,119-121]. In non-human primates, the vaccines have also been shown to elicit populations of antigen-specific Tfh populations that may provide essential help to B cells in the germinal centers of lymph nodes $[117,120]$. Despite the many similarities, only BNT162b2 has been observed to elicit robust antigen-specific $\mathrm{CD}^{+}$cytotoxic $\mathrm{T}$ cell populations, whereas similar populations are limited to undetectable after mRNA-1273 administration [117,119-121]. The potential for these mRNA-based vaccine platforms to elicit both robust antibody and $\mathrm{T}$ cell responses may be incredibly promising for a novel $\mathrm{HCV}$ vaccine candidate, but while the selection of the best antigens will be crucial as previously discussed, the lack of $\mathrm{CD} 8^{+} \mathrm{T}$ cell responses to mRNA-1273 highlights that other components, including the composition of the LNP, may also be essential for eliciting the desired immune responses with such an approach.

\section{Understanding Vaccine Immunogenicity in Populations Most at Risk for HCV}

The ChAd3/MVA-NSmut HCV vaccine elicited robust polyfunctional HCV-specific T cell responses in early phase I immunogenicity trials, making its lack of protection from chronic infection in the phase I/II efficacy trial puzzling. As discussed in the preceding sections, a successful HCV vaccine will likely need to better address viral diversity and potentially incorporate humoral responses to envelope glycoproteins. Another consideration is that the quality of $\mathrm{T}$ cell responses in phase II vaccinees may not have matched the robust responses found in earlier immunogenicity trials. Indeed, the cursory data on immune responses provided with the phase II study suggests that this is the case. Whereas $100 \%$ of phase I participants had IFN- $\gamma$ ELISpot responses to $\geq 4$ of $6 \mathrm{HCV}$ peptide pools spanning HCV proteins NS3-NS5 [53], only 78\% of phase II participants had a measurable response to any peptide pool [48]. Similarly, the combined magnitude of peak HCV-specific IFN- $\gamma$ responses after the 2nd dose of vaccine was substantially lower in the phase II trial (median 428 spot-forming cells per million PBMC in phase II trial versus 2355 in the phase I study).

Reasons for the discrepant immunogenicity results are not yet known, but study population differences may have contributed, particularly with regard to injection drug use [48]. The phase II clinical trial specifically enrolled participants with a known recent history of injection drug use, while earlier phase I immunogenicity studies had excluded individuals with suspected or known injection drug use [53]. The phase II trial established the feasibility of working with PWID in a vaccine clinical trial, an important accomplishment for future $\mathrm{HCV}$ vaccine efficacy studies. However, it is possible that injection drug use may have adversely affected immune responses to the $\mathrm{HCV}$ vaccine, through mechanisms such as immunosuppressive effects of opioids or damping effects of repeated subinfectious exposure to $\mathrm{HCV}$ prior to vaccination, as discussed below. Fully appreciating and accounting for the immune effects of injection drug use will be important for future vaccine trials, particularly those in which PWID are a key high-risk group who could significantly benefit from prophylactic vaccines.

\subsection{Opioid Usage and Effects on Immunity and Vaccines}

An ongoing opioid epidemic has fueled the surge in acute HCV cases in the United States over the last two decades [122]. While the strong association between opioid use 
and HCV infection is mediated principally by viral transmission via shared injection paraphernalia, there has been some concern that opioids may also adversely affect immunity and thus increase susceptibility to $\mathrm{HCV}$ and potentially impair $\mathrm{HCV}$ vaccine responses. Opioid use has been linked to heightened risk of other infectious diseases. including HIV, $\mathrm{TB}$, and pneumonia, and to a higher risk of mortality in sepsis patients [123,124]. Suboptimal seroconversion rates to $\mathrm{HBV}$ vaccine have been noted among individuals injecting heroin compared to healthy adult populations [125]. Supporting these clinical observations, numerous rodent and non-human primate animal model studies, as well as ex vivo human studies, have documented acute and chronic opioid exposure as being associated with impaired bulk $\mathrm{T}$ and $\mathrm{B}$ cell mitogen responses, depressed bulk CD4/CD8 ratios, and altered T helper differentiation away from Th1 responses in bulk populations [126-133]. Innate immune effects include impaired NK cell toxicity and depressed phagocytic activity of monocytes and macrophages [134]. The effects of opioids on immunity may be mediated in part via neuroendocrine or neuroimmune axes, but direct effects on immune cells are also suggested given that defects can be recapitulated with opioid treatment of isolated cells in vitro. This is further supported by the detection of opioid receptor expression by numerous immune cell subsets, particularly following cell activation [135].

A recent study examined the effects of opioid exposure on antiviral gene expression in human PBMCs by single-cell RNA-seq. Following LPS stimulation, PBMCs from individuals with chronic opioid use, and PMBCs from healthy individuals treated with morphine in vitro demonstrated reduced interferon-stimulated gene and antiviral gene expression compared to untreated healthy control PBMCs. This effect was observed in all identified cell subsets including monocytes, $\mathrm{CD}^{+} \mathrm{T}$ cells, $\mathrm{CD} 8^{+} \mathrm{T}$ cells, B cells, and NK cells [136]. Interestingly, morphine treatment of hepatocytes has also been associated with reduced IFN- $\alpha$ production and enhanced HCV replication in vitro [137]. This inhibition of innate defenses may indicate that, regardless of additional inhibition of any adaptive immune functions, opioid users could be more susceptible to $\mathrm{HCV}$ infection and a vaccine response may need to be particularly robust to effectively prevent chronic infection.

Despite the long history of experimental and epidemiologic evidence supporting an immunosuppressive effect of opioids, results have been inconsistent. Some studies have failed to identify in vitro or in vivo effects of opioids on immune cell function. While discrepancies may be in part related to the dosing regimen or type of opioid studied, a more complex relationship between opioids and immunity is likely at play, with recent studies noting an immune-activating effect of chronic opioid exposure [138,139]. Additionally, numerous vaccine immunogenicity studies failed to identify an effect of opioid use on seroconversion [140-142]. Further study of the ChAd3/MVA-NSmut vaccine cohort presents a unique opportunity to explore the effects of injection drug use on a vaccine targeting a $\mathrm{T}$ cell response, if samples obtained during the phase I/II clinical trial can be compared via detailed functional and phenotypic studies to samples obtained during early immunogenicity trials in healthy controls [53].

\subsection{Effects of Sub-Infectious Exposure to HCV on Adaptive Immunity}

While PWID are at a high risk of acquiring HCV due to exposure to infectious doses of $\mathrm{HCV}$ via needle sharing, evidence suggests that this group also frequently encounters minute viral doses that do not lead to sustained viremia and seroconversion. Indeed, a high percentage of HCV RNA-negative seronegative PWID with detectable populations of $\mathrm{HCV}$-specific $\mathrm{T}$ cell populations targeting non-structural proteins have been observed in multiple studies [31,143-145]. Sub-infectious HCV exposure associated with HCVspecific T cell responses and a lack of antibody response has also been documented in other groups, including healthcare workers [146-149], family members of chronically infected patients [150-152], and sexual partners of patients with acute infection [153]. An important caveat is that many of these studies cannot definitively rule out the possibility of previous resolution of acute infection leading to $\mathrm{HCV}$-specific $\mathrm{T}$ cell responses with a loss of detectable antibodies over time [154]. However, prospective studies that followed cohorts 
of healthcare workers after HCV exposure through accidental needlesticks demonstrated that subsequent development of HCV-specific $\mathrm{T}$ cell response without detectable antibodies does occur $[147,148]$.

Low-dose sub-infectious exposures and the development of $\mathrm{T}$ cell responses have been hypothesized to offer some level of immune protection against future infectious exposures to the virus. While this has been difficult to definitively prove with cross-sectional and prospective studies in humans, a study using the chimpanzee model of HCV infection directly assessed this hypothesis [155]. In this study, chimpanzees were given multiple infusions of plasma and an infusion of PBMCs from patients who had trace amounts of $\mathrm{HCV}$ that were below the limit of detection of clinical assays. Two animals that did not develop detectable viremia developed $\mathrm{HCV}$-specific $\mathrm{T}$ cells responses and, when subsequently challenged with infectious doses of $\mathrm{HCV}$, developed significantly higher and sustained viremia with weaker $\mathrm{HCV}$-specific $\mathrm{CD} 4^{+}$and $\mathrm{CD} 8^{+} \mathrm{T}$ cell responses when compared to a chimpanzee that was infected after previously resolving acute HCV infection [155]. Control chimpanzees that received a mock treatment prior to challenge showed a more robust $\mathrm{T}$ cell response after a viral challenge compared to those that were pre-exposed to low viral doses. The authors examined bulk CD4 $4^{+}$Treg cells in the blood and found that the frequency was significantly higher in chimpanzees that were pre-exposed to $\mathrm{HCV}$, and bulk Treg populations expanded more in this group after viral challenge in comparison to control animals. Depletion of these Tregs in vitro resulted in a more significant increase in HCVspecific T cells responses in IFN- $\gamma$ ELISpot assays compared with the depletion of Tregs from control animals, suggesting that the expansion of bulk Treg population contributed to a hampered immune response to HCV challenge after low-dose pre-exposure [155].

The phase I trial of the ChAd3/MVA-NSmut vaccine listed recent injection drug use as an exclusion criterion. HCV-specific T cell responses were not detected in any participants at the onset of the study, suggesting that participants had not been exposed to even low doses of HCV [53]. Vaccinated participants were shown to have bulk Treg frequencies similar to unvaccinated healthy volunteers [53]. In contrast, the phase I/II trial required the involvement of participants at high risk of HCV exposure, namely PWID [48]. Although HCV-specific T cell responses were assessed prior to enrollment and only 3.3\% of evaluated participants in the placebo group were indicated to have $\mathrm{HCV}$-specific $\mathrm{T}$ cell responses after receiving the placebo treatment, $\mathrm{HCV}$-specific $\mathrm{T}$ cell responses in seronegative PWID have often been observed to be somewhat weak, and responses may be under the limit of detection with the methods utilized [31,144,145,148]. Detailed analysis of samples taken before and after vaccination, particularly as it pertains to the frequency of bulk or antigen-specific Treg cells, will be important to determine if potential prior subinfectious exposure could have had any effect on vaccine immunogenicity. Additionally, the potential influence of sub-infectious exposure further suggests that, with a vaccine that will be chiefly important in populations of PWID, involving this population early in phase I safety and immunogenicity trials will be needed to ensure any new vaccine candidate is in fact immunogenic in the target population prior to larger and more complex trials. If immunogenicity in this population is found to be muted, whether due to opioid use or previous sub-infectious exposures, the addition and use of novel adjuvants or vaccine platforms to enhance immunogenicity in PWID may be required. For example, the inclusion of MHC class II-associated invariant chain in a viral vectored $\mathrm{HCV}$ vaccine broadly enhanced $\mathrm{CD} 4^{+}$and $\mathrm{CD} 8^{+} \mathrm{T}$ cell responses over the original vaccine in recently conducted human clinical trials [156].

\subsection{Impact of Chronic Infection and DAA Therapy on Potential Vaccine Success}

Unlike spontaneous resolution of acute HCV infection, cure of chronic HCV infection with DAA therapy does not appear to lead to protective immunity. Reinfection has been described in numerous human cohort studies following successful treatment with DAA or interferon- $\alpha$ /ribavirin therapies $[12,157,158]$, and among individuals with opioid addiction, the risk of reinfection is tied to continued use of injection drugs. Consequently, 
opioid-agonist therapy before or after DAA treatment significantly reduces the risk of reinfection $[12,159]$. Unfortunately, those who are cured with DAA therapy and subsequently reinitiate injection drug use, if reinfected, can reestablish themselves as reservoirs of $\mathrm{HCV}$ and, with continued high-risk behavior, unintentionally infect new people. Curing PWID of HCV and subsequently mitigating the risk of reinfection, through a combination of reducing high-risk behavior and the development of protective immunity, will be an essential component of eliminating HCV.

The lack of protective immune memory against reinfection following DAA cure suggests that immune defects that occur during chronic infection are not fully reversed after the virus is cleared. Major features of the adaptive immune response during chronic infection include loss of HCV-specific CD4 ${ }^{+} \mathrm{T}$ cell help [17,18,26,160-162] and failure of the HCV-specific CD8 ${ }^{+} \mathrm{T}$ cell response due to exhaustion [163-165] or emergence of viral escape mutations that prevent the recognition of $C D 8^{+} \mathrm{T}$ cell epitopes [166-169]. Studies done since the introduction of DAA therapies have begun to shed light on how immunity continues to change after recovery from viral infection and, importantly, how this new immune state is markedly different from that which is observed after spontaneous resolution of infection. It has been observed that $\mathrm{HCV}$-specific $\mathrm{CD} 8^{+} \mathrm{T}$ cell populations expand following DAA-mediated viral clearance $[170,171]$, though in a chimpanzee study, this expansion occurred preferentially in $\mathrm{CD} 8^{+} \mathrm{T}$ cells that were previously dominant and had targeted escaped epitopes [172]. In human studies, expanded HCV-specific $\mathrm{CD}^{+} \mathrm{T}$ cell populations observed post-DAA cure have a better capacity to proliferate and produce antiviral cytokines than prior to treatment, though these cells are neither as proliferative nor as functional as those observed in acute resolving infection $[171,173]$. These cells are a memory-like T cell subset expressing CD127, PD-1, and the transcription factor TCF1 and are distinct from more conventional memory cells that are observed after spontaneous viral clearance. If re-exposed to antigen, the "exhausted memory-like" subset may differentiate into a terminally exhausted subset that are CD127-PD- $1^{\text {high }} \mathrm{TCF}^{-}$, a subset of cells that were present during initial chronic infection and lost after DAA-mediated viral clearance [173]. Recent detailed transcriptional profiling of these $\mathrm{HCV}$-specific $\mathrm{CD} 8^{+} \mathrm{T}$ cell subsets before and after DAA-mediated HCV cure has reinforced the distinct nature of these cells when compared to the memory populations that develop after spontaneous resolution of acute infection [174]. The reduced functionality of $\mathrm{HCV}$-specific $\mathrm{CD} 8^{+} \mathrm{T}$ cells is possibly linked with dysfunctional metabolism that is observed in chronic infection and maintained after DAA therapy [175-177]. Additionally, TOX, a transcription factor linked to transcriptional and epigenetic reprogramming of $\mathrm{CD} 8^{+} \mathrm{T}$ cells and the development of $\mathrm{T}$ cell exhaustion has been found to be highly expressed in HCV-specific CD8 ${ }^{+} \mathrm{T}$ cells during chronic infection and after DAA-mediated viral clearance but not after spontaneous resolution of infection [178]. Comparatively less is known about the $\mathrm{HCV}$-specific $\mathrm{CD}^{+}$ $\mathrm{T}$ cells both during and after chronic HCV infection due to the very low frequency of these cells in peripheral blood after the initial establishment of chronicity. Despite this challenge, several recent studies have demonstrated that the HCV-specific CD4 ${ }^{+} \mathrm{T}$ cell population increases in frequency at least transiently in the peripheral blood during and after DAA treatment $[179,180]$. However, in a study comparing samples from treated patients and vaccinated subjects from human trials, this increase in frequency was not observed [181]. These conflicting results may be explained by differing sampling timelines. Regardless, the frequency of $\mathrm{HCV}$-specific $\mathrm{CD} 4^{+} \mathrm{T}$ cells after DAA treatment is not likely to be comparable to frequencies observed in spontaneous clearance [181]. During and after DAA treatment, $\mathrm{HCV}$-specific $\mathrm{CD} 4^{+} \mathrm{T}$ cells exhibit a decrease in expression of some, but not all, inhibitory receptors, including PD-1, as well as a decrease in the expression of numerous activation markers. Additionally, these cells seem to shift toward a memory phenotype with increased CD127 and TCF1 expression and, strikingly, a shift from a Th1 phenotype to a predominantly follicular helper T cell (Tfh) phenotype $[179,180]$. The ramifications of these phenotypic shifts are not yet fully understood. Collectively, it is clear that chronic 
$\mathrm{HCV}$ infection leaves a lasting imprint on the $\mathrm{HCV}$-specific adaptive immune response even after viral eradication.

In addition to HCV-specific immune exhaustion that occurs as acute infection proceeds to chronicity, some individuals cured of longstanding infection have residual advanced liver fibrosis or cirrhosis that may itself impair innate and adaptive immunity $[182,183]$ and potentially hinder $\mathrm{HCV}$ vaccine responses. For instance, relative to $\mathrm{HCV}$-infected individuals with minimal liver disease (F0-1), those with cirrhosis (F4) have a significant shift of generalized $\mathrm{CD}^{+} \mathrm{T}$ cell phenotype and function towards a hyperfunctional cytotoxic state, and this state persists after DAA cure [184]. Persistent high levels of serum proinflammatory cytokines were also noted after DAA cure in individuals with advanced liver disease [184]. Of concern for secondary HCV prevention through vaccination, cirrhosis has also been associated with impaired IFN- $\gamma$ ELISpot $\mathrm{T}$ cell response to influenza vaccination [185].

While HCV-naïve individuals are the focus population for current HCV vaccine development efforts, evaluating candidate vaccines and novel adjuvant formulations in individuals cured of HCV by DAA therapy with or without advanced cirrhosis will be an important topic of research. If an HCV vaccine is found to be less immunogenic in this group, coupling the vaccine with new therapies to "reverse" the exhausted phenotype of adaptive immunity may also be a consideration. As an example, recent in vitro data suggest that histone methyltransferase inhibitors or p53 inhibitors may have the ability to restore $\mathrm{CD} 8^{+} \mathrm{T}$ cell functionality and proliferative capacity [176]. With a number of histone methyltransferase inhibitors already in clinical trials for cancer therapy [186], the possibility of repurposing one or more of them for treatment coupled to DAA therapy and/or vaccination to potentially increase the functional capacity of previously exhausted $\mathrm{CD}^{+} \mathrm{T}$ cells is intriguing.

\section{Conclusions}

Despite the development of potent DAA therapies, a prophylactic vaccine is urgently needed to eliminate the public health burden of HCV. The recent failure of the ChAd3 /MVANSmut regimen in the first large-scale clinical trial of an HCV vaccine was unquestionably a considerable disappointment. Nevertheless, data from this trial, along with recent advances in our understanding of HCV immunity and continued advancement in vaccine immunogen design and delivery systems, offer direction for developing and testing the next generation of $\mathrm{HCV}$ vaccines.

Author Contributions: C.C.P., C.M.W. and J.R.H. conceptualized the review. C.C.P. prepared the original draft. C.C.P., C.M.W. and J.R.H. revised and edited the manuscript. C.M.W. and J.R.H. secured funding. All authors have read and agreed to the published version of the manuscript.

Funding: This work was conducted with support from the National Institute of Allergy and Infectious Diseases of the National Institutes of Health (R01AI096882, R01AI126890, and U01AI131313).

Institutional Review Board Statement: Not applicable.

Informed Consent Statement: Not applicable.

Conflicts of Interest: The authors declare no conflict of interest.
Abbreviations
HCV Hepatitis C Virus
DAA Direct-acting antiviral
PWID People who inject drugs
LNP Lipid nanoparticles 


\section{References}

1. Choo, Q.L.; Kuo, G.; Weiner, A.J.; Overby, L.R.; Bradley, D.W.; Houghton, M. Isolation of a cDNA clone derived from a blood-borne non-A, non-B viral hepatitis genome. Science 1989, 244, 359-362. [CrossRef]

2. Polaris Observatory HCV Collaborators. Global prevalence and genotype distribution of hepatitis C virus infection in 2015: A modelling study. Lancet Gastroenterol. Hepatol. 2017, 2, 161-176. [CrossRef]

3. WHO. Global Hepatitis Report, 2017; World Health Organization: Geneva, Switzerland, 2017.

4. Feld, J.J.; Jacobson, I.M.; Hézode, C.; Asselah, T.; Ruane, P.J.; Gruener, N.; Abergel, A.; Mangia, A.; Lai, C.L.; Chan, H.L.; et al. Sofosbuvir and Velpatasvir for HCV Genotype 1, 2, 4, 5, and 6 Infection. N. Engl. J. Med. 2015, 373, 2599-2607. [CrossRef]

5. WHO. Global Health Sector Strategy on Viral Hepatitis 2016-2021; World Health Organization: Geneva, Switzerland, 2016.

6. Centers for Disease Control and Prevention. Viral Hepatitis Surveillance-United States. 2018. Available online: https://www.cdc. gov/hepatitis/statistics/SurveillanceRpts.htm (accessed on 27 January 2021).

7. Dore, G.J.; Ward, J.; Thursz, M. Hepatitis C disease burden and strategies to manage the burden (Guest Editors Mark Thursz, Gregory Dore and John Ward). J. Viral. Hepat. 2014, 21 (Suppl. 1), 1-4. [CrossRef]

8. Bailey, J.R.; Barnes, E.; Cox, A.L. Approaches, Progress, and Challenges to Hepatitis C Vaccine Development. Gastroenterology 2019, 156, 418-430. [CrossRef]

9. Dore, G.J.; Feld, J.J. Hepatitis C virus therapeutic development: In pursuit of "perfectovir". Clin. Infect. Dis. Off. Publ. Infect. Dis. Soc. Am. 2015, 60, 1829-1836. [CrossRef] [PubMed]

10. Vermehren, J.; Sarrazin, C. The role of resistance in HCV treatment. Best Pract. Res. Clin. Gastroenterol. 2012, $26,487-503$. [CrossRef] [PubMed]

11. Wyles, D.L.; Luetkemeyer, A.F. Understanding Hepatitis C Virus Drug Resistance: Clinical Implications for Current and Future Regimens. Top. Antivir. Med. 2017, 25, 103-109.

12. Hajarizadeh, B.; Cunningham, E.B.; Valerio, H.; Martinello, M.; Law, M.; Janjua, N.Z.; Midgard, H.; Dalgard, O.; Dillon, J.; Hickman, M.; et al. Hepatitis C reinfection after successful antiviral treatment among people who inject drugs: A meta-analysis. J. Hepatol. 2020, 72, 643-657. [CrossRef] [PubMed]

13. Hahn, J.A.; Wylie, D.; Dill, J.; Sanchez, M.S.; Lloyd-Smith, J.O.; Page-Shafer, K.; Getz, W.M. Potential impact of vaccination on the hepatitis $C$ virus epidemic in injection drug users. Epidemics 2009, 1, 47-57. [CrossRef]

14. Scott, N.; McBryde, E.; Vickerman, P.; Martin, N.K.; Stone, J.; Drummer, H.; Hellard, M. The role of a hepatitis C virus vaccine: Modelling the benefits alongside direct-acting antiviral treatments. BMC Med. 2015, 13, 198. [CrossRef] [PubMed]

15. De Oliveria Andrade, L.J.; D'Oliveira, A.; Melo, R.C.; De Souza, E.C.; Costa Silva, C.A.; Parana, R. Association between hepatitis $\mathrm{C}$ and hepatocellular carcinoma. J. Glob. Infect. Dis. 2009, 1, 33-37. [CrossRef] [PubMed]

16. Osburn, W.O.; Fisher, B.E.; Dowd, K.A.; Urban, G.; Liu, L.; Ray, S.C.; Thomas, D.L.; Cox, A.L. Spontaneous control of primary hepatitis C virus infection and immunity against persistent reinfection. Gastroenterology 2010, 138, 315-324. [CrossRef]

17. Schulze Zur Wiesch, J.; Ciuffreda, D.; Lewis-Ximenez, L.; Kasprowicz, V.; Nolan, B.E.; Streeck, H.; Aneja, J.; Reyor, L.L.; Allen, T.M.; Lohse, A.W.; et al. Broadly directed virus-specific CD4+ T cell responses are primed during acute hepatitis C infection, but rapidly disappear from human blood with viral persistence. J. Exp. Med. 2012, 209, 61-75. [CrossRef]

18. Schulze zur Wiesch, J.; Lauer, G.M.; Day, C.L.; Kim, A.Y.; Ouchi, K.; Duncan, J.E.; Wurcel, A.G.; Timm, J.; Jones, A.M.; Mothe, B.; et al. Broad repertoire of the CD4+ Th cell response in spontaneously controlled hepatitis $\mathrm{C}$ virus infection includes dominant and highly promiscuous epitopes. J. Immunol. 2005, 175, 3603-3613. [CrossRef]

19. Lauer, G.M.; Barnes, E.; Lucas, M.; Timm, J.; Ouchi, K.; Kim, A.Y.; Day, C.L.; Robbins, G.K.; Casson, D.R.; Reiser, M.; et al. High resolution analysis of cellular immune responses in resolved and persistent hepatitis C virus infection. Gastroenterology 2004, 127, 924-936. [CrossRef]

20. Smyk-Pearson, S.; Tester, I.A.; Lezotte, D.; Sasaki, A.W.; Lewinsohn, D.M.; Rosen, H.R. Differential antigenic hierarchy associated with spontaneous recovery from hepatitis C virus infection: Implications for vaccine design. J. Infect. Dis. 2006, 194, 454-463. [CrossRef]

21. Thimme, R.; Bukh, J.; Spangenberg, H.C.; Wieland, S.; Pemberton, J.; Steiger, C.; Govindarajan, S.; Purcell, R.H.; Chisari, F.V. Viral and immunological determinants of hepatitis C virus clearance, persistence, and disease. Proc. Natl. Acad. Sci. USA 2002, 99, 15661-15668. [CrossRef]

22. Thimme, R.; Oldach, D.; Chang, K.M.; Steiger, C.; Ray, S.C.; Chisari, F.V. Determinants of viral clearance and persistence during acute hepatitis C virus infection. J. Exp. Med. 2001, 194, 1395-1406. [CrossRef] [PubMed]

23. Lechner, F.; Wong, D.K.; Dunbar, P.R.; Chapman, R.; Chung, R.T.; Dohrenwend, P.; Robbins, G.; Phillips, R.; Klenerman, P.; Walker, B.D. Analysis of successful immune responses in persons infected with hepatitis C virus. J. Exp. Med. 2000, 191, 1499-1512. [CrossRef]

24. Grakoui, A.; Shoukry, N.H.; Woollard, D.J.; Han, J.H.; Hanson, H.L.; Ghrayeb, J.; Murthy, K.K.; Rice, C.M.; Walker, C.M. HCV persistence and immune evasion in the absence of memory T cell help. Science 2003, 302, 659-662. [CrossRef]

25. Shoukry, N.H.; Grakoui, A.; Houghton, M.; Chien, D.Y.; Ghrayeb, J.; Reimann, K.A.; Walker, C.M. Memory CD8+ T cells are required for protection from persistent hepatitis C virus infection. J. Exp. Med. 2003, 197, 1645-1655. [CrossRef]

26. Chen, D.Y.; Wolski, D.; Aneja, J.; Matsubara, L.; Robilotti, B.; Hauck, G.; de Sousa, P.S.F.; Subudhi, S.; Fernandes, C.A.; Hoogeveen, R.C.; et al. Hepatitis C virus-specific CD4+ T cell phenotype and function in different infection outcomes. J. Clin. Investig. 2020, 130, 768-773. [CrossRef] 
27. Gruener, N.H.; Lechner, F.; Jung, M.C.; Diepolder, H.; Gerlach, T.; Lauer, G.; Walker, B.; Sullivan, J.; Phillips, R.; Pape, G.R.; et al. Sustained dysfunction of antiviral CD8+ T lymphocytes after infection with hepatitis C virus. J. Virol. 2001, 75, 5550-5558. [CrossRef] [PubMed]

28. Wedemeyer, H.; He, X.S.; Nascimbeni, M.; Davis, A.R.; Greenberg, H.B.; Hoofnagle, J.H.; Liang, T.J.; Alter, H.; Rehermann, B. Impaired effector function of hepatitis $C$ virus-specific CD8+ T cells in chronic hepatitis $C$ virus infection. J. Immunol. 2002, 169, 3447-3458. [CrossRef] [PubMed]

29. Adams, G.; Kuntz, S.; Rabalais, G.; Bratcher, D.; Tamburro, C.H.; Kotwal, G.J. Natural recovery from acute hepatitis C virus infection by agammaglobulinemic twin children. Pediatr. Infect. Dis. J. 1997, 16, 533-534. [CrossRef]

30. Post, J.J.; Pan, Y.; Freeman, A.J.; Harvey, C.E.; White, P.A.; Palladinetti, P.; Haber, P.S.; Marinos, G.; Levy, M.H.; Kaldor, J.M.; et al. Clearance of hepatitis $C$ viremia associated with cellular immunity in the absence of seroconversion in the hepatitis $C$ incidence and transmission in prisons study cohort. J. Infect. Dis. 2004, 189, 1846-1855. [CrossRef]

31. Zeremski, M.; Shu, M.A.; Brown, Q.; Wu, Y.; Des Jarlais, D.C.; Busch, M.P.; Talal, A.H.; Edlin, B.R. Hepatitis C virus-specific T-cell immune responses in seronegative injection drug users. J. Viral Hepat. 2009, 16, 10-20. [CrossRef]

32. Bartosch, B.; Bukh, J.; Meunier, J.C.; Granier, C.; Engle, R.E.; Blackwelder, W.C.; Emerson, S.U.; Cosset, F.L.; Purcell, R.H. In vitro assay for neutralizing antibody to hepatitis $\mathrm{C}$ virus: Evidence for broadly conserved neutralization epitopes. Proc. Natl. Acad. Sci. USA 2003, 100, 14199-14204. [CrossRef] [PubMed]

33. Logvinoff, C.; Major, M.E.; Oldach, D.; Heyward, S.; Talal, A.; Balfe, P.; Feinstone, S.M.; Alter, H.; Rice, C.M.; McKeating, J.A. Neutralizing antibody response during acute and chronic hepatitis C virus infection. Proc. Natl. Acad. Sci. USA 2004, 101, 10149-10154. [CrossRef]

34. Farci, P.; Alter, H.J.; Wong, D.C.; Miller, R.H.; Govindarajan, S.; Engle, R.; Shapiro, M.; Purcell, R.H. Prevention of hepatitis C virus infection in chimpanzees after antibody-mediated in vitro neutralization. Proc. Natl. Acad. Sci. USA 1994, 91, 7792-7796. [CrossRef]

35. Law, M.; Maruyama, T.; Lewis, J.; Giang, E.; Tarr, A.W.; Stamataki, Z.; Gastaminza, P.; Chisari, F.V.; Jones, I.M.; Fox, R.I.; et al. Broadly neutralizing antibodies protect against hepatitis $C$ virus quasispecies challenge. Nat. Med. 2008, 14, 25-27. [CrossRef]

36. Morin, T.J.; Broering, T.J.; Leav, B.A.; Blair, B.M.; Rowley, K.J.; Boucher, E.N.; Wang, Y.; Cheslock, P.S.; Knauber, M.; Olsen, D.B.; et al. Human monoclonal antibody HCV1 effectively prevents and treats HCV infection in chimpanzees. PLoS Pathog. 2012, 8, e1002895. [CrossRef] [PubMed]

37. Choo, Q.L.; Kuo, G.; Ralston, R.; Weiner, A.; Chien, D.; Van Nest, G.; Han, J.; Berger, K.; Thudium, K.; Kuo, C.; et al. Vaccination of chimpanzees against infection by the hepatitis C virus. Proc. Natl. Acad. Sci. USA 1994, 91, 1294-1298. [CrossRef]

38. Houghton, M. Prospects for prophylactic and therapeutic vaccines against the hepatitis $C$ viruses. Immunol. Rev. 2011, 239, 99-108. [CrossRef] [PubMed]

39. Pestka, J.M.; Zeisel, M.B.; Bläser, E.; Schürmann, P.; Bartosch, B.; Cosset, F.L.; Patel, A.H.; Meisel, H.; Baumert, J.; Viazov, S.; et al. Rapid induction of virus-neutralizing antibodies and viral clearance in a single-source outbreak of hepatitis C. Proc. Natl. Acad. Sci. USA 2007, 104, 6025-6030. [CrossRef]

40. Osburn, W.O.; Snider, A.E.; Wells, B.L.; Latanich, R.; Bailey, J.R.; Thomas, D.L.; Cox, A.L.; Ray, S.C. Clearance of hepatitis C infection is associated with the early appearance of broad neutralizing antibody responses. Hepatology 2014, 59, 2140-2151. [CrossRef]

41. Duncan, J.D.; Urbanowicz, R.A.; Tarr, A.W.; Ball, J.K. Hepatitis C Virus Vaccine: Challenges and Prospects. Vaccines 2020, 8, 90. [CrossRef] [PubMed]

42. Stoll-Keller, F.; Barth, H.; Fafi-Kremer, S.; Zeisel, M.B.; Baumert, T.F. Development of hepatitis C virus vaccines: Challenges and progress. Expert Rev. Vaccines 2009, 8, 333-345. [CrossRef]

43. Thomas, E.; Liang, T.J. Experimental models of hepatitis B and C-New insights and progress. Nat. Rev. Gastroenterol. Hepatol. 2016, 13, 362-374. [CrossRef]

44. Trivedi, S.; Murthy, S.; Sharma, H.; Hartlage, A.S.; Kumar, A.; Gadi, S.V.; Simmonds, P.; Chauhan, L.V.; Scheel, T.K.H.; Billerbeck, E.; et al. Viral persistence, liver disease, and host response in a hepatitis C-like virus rat model. Hepatology 2018, 68, 435-448. [CrossRef]

45. Thimme, R. T cell immunity to hepatitis C virus: Lessons for a prophylactic HCV vaccine. J. Hepatol. 2020. [CrossRef]

46. Cox, A.L.; Page, K.; Bruneau, J.; Shoukry, N.H.; Lauer, G.M.; Kim, A.Y.; Rosen, H.R.; Radziewicz, H.; Grakoui, A.; Fierer, D.S.; et al. Rare birds in North America: Acute hepatitis C cohorts. Gastroenterology 2009, 136, 26-31. [CrossRef]

47. Edlin, B.R.; Shu, M.A.; Winkelstein, E.; Des Jarlais, D.C.; Busch, M.P.; Rehermann, B.; O’Brien, T.R.; Talal, A.H.; Tobler, L.H.; Zeremski, M.; et al. More rare birds, and the occasional swan. Gastroenterology 2009, 136, 2412-2414. [CrossRef]

48. Page, K.; Melia, M.T.; Veenhuis, R.T.; Winter, M.; Rousseau, K.E.; Massaccesi, G.; Osburn, W.O.; Forman, M.; Thomas, E.; Thornton, K.; et al. Randomized Trial of a Vaccine Regimen to Prevent Chronic HCV Infection. N. Engl. J. Med. 2021, 384, 541-549. [CrossRef] [PubMed]

49. Folgori, A.; Capone, S.; Ruggeri, L.; Meola, A.; Sporeno, E.; Ercole, B.B.; Pezzanera, M.; Tafi, R.; Arcuri, M.; Fattori, E.; et al. A T-cell HCV vaccine eliciting effective immunity against heterologous virus challenge in chimpanzees. Nat. Med. 2006, 12, 190-197. [CrossRef] 
50. Capone, S.; Meola, A.; Ercole, B.B.; Vitelli, A.; Pezzanera, M.; Ruggeri, L.; Davies, M.E.; Tafi, R.; Santini, C.; Luzzago, A.; et al. A novel adenovirus type 6 (Ad6)-based hepatitis $C$ virus vector that overcomes preexisting anti-ad5 immunity and induces potent and broad cellular immune responses in rhesus macaques. J. Virol. 2006, 80, 1688-1699. [CrossRef] [PubMed]

51. Colloca, S.; Barnes, E.; Folgori, A.; Ammendola, V.; Capone, S.; Cirillo, A.; Siani, L.; Naddeo, M.; Grazioli, F.; Esposito, M.L.; et al. Vaccine vectors derived from a large collection of simian adenoviruses induce potent cellular immunity across multiple species. Sci. Transl. Med. 2012, 4, 115ra112. [CrossRef] [PubMed]

52. Barnes, E.; Folgori, A.; Capone, S.; Swadling, L.; Aston, S.; Kurioka, A.; Meyer, J.; Huddart, R.; Smith, K.; Townsend, R.; et al. Novel adenovirus-based vaccines induce broad and sustained T cell responses to HCV in man. Sci. Transl. Med. 2012, 4, $115 \mathrm{ra} 111$. [CrossRef]

53. Swadling, L.; Capone, S.; Antrobus, R.D.; Brown, A.; Richardson, R.; Newell, E.W.; Halliday, J.; Kelly, C.; Bowen, D.; Fergusson, J.; et al . A human vaccine strategy based on chimpanzee adenoviral and MVA vectors that primes, boosts, and sustains functional HCV-specific T cell memory. Sci. Transl. Med. 2014, 6, 261ra153. [CrossRef]

54. Yusim, K.; Fischer, W.; Yoon, H.; Thurmond, J.; Fenimore, P.W.; Lauer, G.; Korber, B.; Kuiken, C. Genotype 1 and global hepatitis C T-cell vaccines designed to optimize coverage of genetic diversity. J. Gen. Virol. 2010, 91, 1194-1206. [CrossRef] [PubMed]

55. Torres-Cornejo, A.; Lauer, G.M. Hurdles to the Development of Effective HBV Immunotherapies and HCV Vaccines. Pathog. Immun. 2017, 2, 102-125. [CrossRef]

56. Smith, D.B.; Bukh, J.; Kuiken, C.; Muerhoff, A.S.; Rice, C.M.; Stapleton, J.T.; Simmonds, P. Expanded classification of hepatitis C virus into 7 genotypes and 67 subtypes: Updated criteria and genotype assignment web resource. Hepatology 2014, 59, 318-327. [CrossRef] [PubMed]

57. Lanford, R.E.; Guerra, B.; Chavez, D.; Bigger, C.; Brasky, K.M.; Wang, X.H.; Ray, S.C.; Thomas, D.L. Cross-genotype immunity to hepatitis C virus. J. Virol. 2004, 78, 1575-1581. [CrossRef] [PubMed]

58. Bukh, J.; Thimme, R.; Meunier, J.C.; Faulk, K.; Spangenberg, H.C.; Chang, K.M.; Satterfield, W.; Chisari, F.V.; Purcell, R.H. Previously infected chimpanzees are not consistently protected against reinfection or persistent infection after reexposure to the identical hepatitis C virus strain. J. Virol. 2008, 82, 8183-8195. [CrossRef]

59. Prince, A.M.; Brotman, B.; Lee, D.H.; Pfahler, W.; Tricoche, N.; Andrus, L.; Shata, M.T. Protection against chronic hepatitis C virus infection after rechallenge with homologous, but not heterologous, genotypes in a chimpanzee model. J. Infect. Dis. 2005, 192, 1701-1709. [CrossRef]

60. Schulze Zur Wiesch, J.; Lauer, G.M.; Timm, J.; Kuntzen, T.; Neukamm, M.; Berical, A.; Jones, A.M.; Nolan, B.E.; Longworth, S.A.; Kasprowicz, V.; et al. Immunologic evidence for lack of heterologous protection following resolution of HCV in patients with non-genotype 1 infection. Blood 2007, 110, 1559-1569. [CrossRef]

61. Von Delft, A.; Humphreys, I.S.; Brown, A.; Pfafferott, K.; Lucas, M.; Klenerman, P.; Lauer, G.M.; Cox, A.L.; Gaudieri, S.; Barnes, E. The broad assessment of HCV genotypes 1 and 3 antigenic targets reveals limited cross-reactivity with implications for vaccine design. Gut 2016, 65, 112-123. [CrossRef]

62. Letourneau, S.; Im, E.J.; Mashishi, T.; Brereton, C.; Bridgeman, A.; Yang, H.; Dorrell, L.; Dong, T.; Korber, B.; McMichael, A.J.; et al. Design and pre-clinical evaluation of a universal HIV-1 vaccine. PLoS ONE 2007, 2, e984. [CrossRef] [PubMed]

63. Rosario, M.; Bridgeman, A.; Quakkelaar, E.D.; Quigley, M.F.; Hill, B.J.; Knudsen, M.L.; Ammendola, V.; Ljungberg, K.; Borthwick, N.; Im, E.J.; et al. Long peptides induce polyfunctional T cells against conserved regions of HIV-1 with superior breadth to single-gene vaccines in macaques. Eur. J. Immunol. 2010, 40, 1973-1984. [CrossRef]

64. Borthwick, N.; Ahmed, T.; Ondondo, B.; Hayes, P.; Rose, A.; Ebrahimsa, U.; Hayton, E.J.; Black, A.; Bridgeman, A.; Rosario, M.; et al. Vaccine-elicited human T cells recognizing conserved protein regions inhibit HIV-1. Mol. Ther. 2014, 22, 464-475. [CrossRef] [PubMed]

65. Moyo, N.; Borthwick, N.J.; Wee, E.G.; Capucci, S.; Crook, A.; Dorrell, L.; Hanke, T. Long-term follow up of human T-cell responses to conserved HIV-1 regions elicited by DNA/simian adenovirus/MVA vaccine regimens. PLoS ONE 2017, 12, e0181382. [CrossRef]

66. Koopman, G.; Beenhakker, N.; Nieuwenhuis, I.; Doxiadis, G.; Mooij, P.; Drijfhout, J.W.; Koestler, J.; Hanke, T.; Fagrouch, Z.; Verschoor, E.J.; et al. DNA/long peptide vaccination against conserved regions of SIV induces partial protection against SIVmac251 challenge. AIDS 2013, 27, 2841-2851. [CrossRef]

67. Von Delft, A.; Donnison, T.A.; Lourenco, J.; Hutchings, C.; Mullarkey, C.E.; Brown, A.; Pybus, O.G.; Klenerman, P.; Chinnakannan, S.; Barnes, E. The generation of a simian adenoviral vectored HCV vaccine encoding genetically conserved gene segments to target multiple HCV genotypes. Vaccine 2018, 36, 313-321. [CrossRef] [PubMed]

68. Donnison, T.; von Delft, A.; Brown, A.; Swadling, L.; Hutchings, C.; Hanke, T.; Chinnakannan, S.; Barnes, E. Viral vectored hepatitis $C$ virus vaccines generate pan-genotypic $T$ cell responses to conserved subdominant epitopes. Vaccine 2020, 38, 5036-5048. [CrossRef]

69. Fischer, W.; Perkins, S.; Theiler, J.; Bhattacharya, T.; Yusim, K.; Funkhouser, R.; Kuiken, C.; Haynes, B.; Letvin, N.L.; Walker, B.D.; et al. Polyvalent vaccines for optimal coverage of potential T-cell epitopes in global HIV-1 variants. Nat. Med. 2007, 13, 100-106. [CrossRef]

70. Theiler, J.; Korber, B. Graph-based optimization of epitope coverage for vaccine antigen design. Stat. Med. 2018, 37, 181-194. [CrossRef] 
71. Theiler, J.; Yoon, H.; Yusim, K.; Picker, L.J.; Fruh, K.; Korber, B. Epigraph: A Vaccine Design Tool Applied to an HIV Therapeutic Vaccine and a Pan-Filovirus Vaccine. Sci. Rep. 2016, 6, 33987. [CrossRef] [PubMed]

72. Korber, B.; Fischer, W. T cell-based strategies for HIV-1 vaccines. Hum. Vaccines Immunother. 2020, 16, 713-722. [CrossRef]

73. Barouch, D.H.; O’Brien, K.L.; Simmons, N.L.; King, S.L.; Abbink, P.; Maxfield, L.F.; Sun, Y.H.; La Porte, A.; Riggs, A.M.; Lynch, D.M.; et al. Mosaic HIV-1 vaccines expand the breadth and depth of cellular immune responses in rhesus monkeys. Nat. Med. 2010, 16, 319-323. [CrossRef] [PubMed]

74. Santra, S.; Liao, H.X.; Zhang, R.; Muldoon, M.; Watson, S.; Fischer, W.; Theiler, J.; Szinger, J.; Balachandran, H.; Buzby, A.; et al. Mosaic vaccines elicit CD8+ T lymphocyte responses that confer enhanced immune coverage of diverse HIV strains in monkeys. Nat. Med. 2010, 16, 324-328. [CrossRef]

75. Barouch, D.H.; Stephenson, K.E.; Borducchi, E.N.; Smith, K.; Stanley, K.; McNally, A.G.; Liu, J.; Abbink, P.; Maxfield, L.F.; Seaman, M.S.; et al. Protective efficacy of a global HIV-1 mosaic vaccine against heterologous SHIV challenges in rhesus monkeys. Cell 2013, 155, 531-539. [CrossRef] [PubMed]

76. Baden, L.R.; Walsh, S.R.; Seaman, M.S.; Cohen, Y.Z.; Johnson, J.A.; Licona, J.H.; Filter, R.D.; Kleinjan, J.A.; Gothing, J.A.; Jennings, J.; et al. First-in-Human Randomized, Controlled Trial of Mosaic HIV-1 Immunogens Delivered via a Modified Vaccinia Ankara Vector. J. Infect. Dis. 2018, 218, 633-644. [CrossRef]

77. Barouch, D.H.; Tomaka, F.L.; Wegmann, F.; Stieh, D.J.; Alter, G.; Robb, M.L.; Michael, N.L.; Peter, L.; Nkolola, J.P.; Borducchi, E.N.; et al. Evaluation of a mosaic HIV-1 vaccine in a multicentre, randomised, double-blind, placebo-controlled, phase 1/2a clinical trial (APPROACH) and in rhesus monkeys (NHP 13-19). Lancet 2018, 392, 232-243. [CrossRef]

78. Yusim, K.; Dilan, R.; Borducchi, E.; Stanley, K.; Giorgi, E.; Fischer, W.; Theiler, J.; Marcotrigiano, J.; Korber, B.; Barouch, D.H. Hepatitis $\mathrm{C}$ genotype 1 mosaic vaccines are immunogenic in mice and induce stronger T-cell responses than natural strains. Clin. Vaccine Immunol. 2013, 20, 302-305. [CrossRef] [PubMed]

79. Ondondo, B.; Murakoshi, H.; Clutton, G.; Abdul-Jawad, S.; Wee, E.G.; Gatanaga, H.; Oka, S.; McMichael, A.J.; Takiguchi, M.; Korber, B.; et al. Novel Conserved-region T-cell Mosaic Vaccine With High Global HIV-1 Coverage Is Recognized by Protective Responses in Untreated Infection. Mol. Ther. 2016, 24, 832-842. [CrossRef]

80. Dowd, K.A.; Netski, D.M.; Wang, X.H.; Cox, A.L.; Ray, S.C. Selection pressure from neutralizing antibodies drives sequence evolution during acute infection with hepatitis C virus. Gastroenterology 2009, 136, 2377-2386. [CrossRef] [PubMed]

81. Walker, M.R.; Leung, P.; Eltahla, A.A.; Underwood, A.; Abayasingam, A.; Brasher, N.A.; Li, H.; Wu, B.R.; Maher, L.; Luciani, F.; et al. Clearance of hepatitis $C$ virus is associated with early and potent but narrowly-directed, Envelope-specific antibodies. Sci. Rep. 2019, 9, 13300. [CrossRef]

82. Kinchen, V.J.; Zahid, M.N.; Flyak, A.I.; Soliman, M.G.; Learn, G.H.; Wang, S.; Davidson, E.; Doranz, B.J.; Ray, S.C.; Cox, A.L.; et al. Broadly Neutralizing Antibody Mediated Clearance of Human Hepatitis C Virus Infection. Cell Host Microbe 2018, 24, 717-730. [CrossRef]

83. Salinas, E.; Boisvert, M.; Upadhyay, A.A.; Bedard, N.; Nelson, S.A.; Bruneau, J.; Derdeyn, C.A.; Marcotrigiano, J.; Evans, M.J.; Bosinger, S.E.; et al. Early T follicular helper cell activity accelerates hepatitis C virus-specific B cell expansion. J. Clin. Investig. 2021, 131, e140590. [CrossRef]

84. Dahari, H.; Feinstone, S.M.; Major, M.E. Meta-analysis of hepatitis C virus vaccine efficacy in chimpanzees indicates an importance for structural proteins. Gastroenterology 2010, 139, 965-974. [CrossRef] [PubMed]

85. Meunier, J.C.; Gottwein, J.M.; Houghton, M.; Russell, R.S.; Emerson, S.U.; Bukh, J.; Purcell, R.H. Vaccine-induced cross-genotype reactive neutralizing antibodies against hepatitis C virus. J. Infect. Dis. 2011, 204, 1186-1190. [CrossRef]

86. Frey, S.E.; Houghton, M.; Coates, S.; Abrignani, S.; Chien, D.; Rosa, D.; Pileri, P.; Ray, R.; Di Bisceglie, A.M.; Rinella, P.; et al. Safety and immunogenicity of HCV E1E2 vaccine adjuvanted with MF59 administered to healthy adults. Vaccine 2010, 28, 6367-6373. [CrossRef] [PubMed]

87. Chen, F.; Nagy, K.; Chavez, D.; Willis, S.; McBride, R.; Giang, E.; Honda, A.; Bukh, J.; Ordoukhanian, P.; Zhu, J.; et al. Antibody Responses to Immunization With HCV Envelope Glycoproteins as a Baseline for B-Cell-Based Vaccine Development. Gastroenterology 2020, 158, 1058-1071.e6. [CrossRef] [PubMed]

88. Law, J.L.; Chen, C.; Wong, J.; Hockman, D.; Santer, D.M.; Frey, S.E.; Belshe, R.B.; Wakita, T.; Bukh, J.; Jones, C.T.; et al. A hepatitis $\mathrm{C}$ virus (HCV) vaccine comprising envelope glycoproteins gpE1/gpE2 derived from a single isolate elicits broad cross-genotype neutralizing antibodies in humans. PLoS ONE 2013, 8, e59776. [CrossRef] [PubMed]

89. Bailey, J.R.; Flyak, A.I.; Cohen, V.J.; Li, H.; Wasilewski, L.N.; Snider, A.E.; Wang, S.; Learn, G.H.; Kose, N.; Loerinc, L.; et al. Broadly neutralizing antibodies with few somatic mutations and hepatitis C virus clearance. JCI Insight 2017, 2, e92872. [CrossRef] [PubMed]

90. Merat, S.J.; Bru, C.; van de Berg, D.; Molenkamp, R.; Tarr, A.W.; Koekkoek, S.; Kootstra, N.A.; Prins, M.; Ball, J.K.; Bakker, A.Q.; et al. Cross-genotype AR3-specific neutralizing antibodies confer long-term protection in injecting drug users after $\mathrm{HCV}$ clearance. J. Hepatol. 2019, 71, 14-24. [CrossRef]

91. Merat, S.J.; Molenkamp, R.; Wagner, K.; Koekkoek, S.M.; van de Berg, D.; Yasuda, E.; Bohne, M.; Claassen, Y.B.; Grady, B.P.; Prins, M.; et al. Hepatitis C virus Broadly Neutralizing Monoclonal Antibodies Isolated 25 Years after Spontaneous Clearance. PLoS ONE 2016, 11, e0165047. [CrossRef] 
92. Chen, F.; Tzarum, N.; Lin, X.; Giang, E.; Velazquez-Moctezuma, R.; Augestad, E.H.; Nagy, K.; He, L.; Hernandez, M.; Fouch, M.E.; et al. Functional convergence of a germline-encoded neutralizing antibody response in rhesus macaques immunized with $\mathrm{HCV}$ envelope glycoproteins. Immunity 2021, 54, 781-796.e4. [CrossRef]

93. Yechezkel, I.; Law, M.; Tzarum, N. From Structural Studies to HCV Vaccine Design. Viruses 2021, 13, 833. [CrossRef]

94. Schlotthauer, F.; McGregor, J.; Drummer, H.E. To Include or Occlude: Rational Engineering of HCV Vaccines for Humoral Immunity. Viruses 2021, 13, 805. [CrossRef]

95. Toth, E.A.; Chagas, A.; Pierce, B.G.; Fuerst, T.R. Structural and Biophysical Characterization of the HCV E1E2 Heterodimer for Vaccine Development. Viruses 2021, 13, 1027. [CrossRef]

96. Bankwitz, D.; Steinmann, E.; Bitzegeio, J.; Ciesek, S.; Friesland, M.; Herrmann, E.; Zeisel, M.B.; Baumert, T.F.; Keck, Z.Y.; Foung, S.K.; et al. Hepatitis C virus hypervariable region 1 modulates receptor interactions, conceals the CD81 binding site, and protects conserved neutralizing epitopes. J. Virol. 2010, 84, 5751-5763. [CrossRef]

97. Keck, Z.Y.; Girard-Blanc, C.; Wang, W.; Lau, P.; Zuiani, A.; Rey, F.A.; Krey, T.; Diamond, M.S.; Foung, S.K. Antibody Response to Hypervariable Region 1 Interferes with Broadly Neutralizing Antibodies to Hepatitis C Virus. J. Virol. 2016, 90, 3112-3122. [CrossRef] [PubMed]

98. Prentoe, J.; Velázquez-Moctezuma, R.; Foung, S.K.; Law, M.; Bukh, J. Hypervariable region 1 shielding of hepatitis C virus is a main contributor to genotypic differences in neutralization sensitivity. Hepatology 2016, 64, 1881-1892. [CrossRef] [PubMed]

99. Liu, L.; Fisher, B.E.; Dowd, K.A.; Astemborski, J.; Cox, A.L.; Ray, S.C. Acceleration of hepatitis C virus envelope evolution in humans is consistent with progressive humoral immune selection during the transition from acute to chronic infection. J. Virol. 2010, 84, 5067-5077. [CrossRef] [PubMed]

100. Pierce, B.G.; Keck, Z.Y.; Wang, R.; Lau, P.; Garagusi, K.; Elkholy, K.; Toth, E.A.; Urbanowicz, R.A.; Guest, J.D.; Agnihotri, P.; et al. Structure-Based Design of Hepatitis C Virus E2 Glycoprotein Improves Serum Binding and Cross-Neutralization. J. Virol. 2020, 94. [CrossRef]

101. Law, J.L.M.; Logan, M.; Wong, J.; Kundu, J.; Hockman, D.; Landi, A.; Chen, C.; Crawford, K.; Wininger, M.; Johnson, J.; et al. Role of the E2 Hypervariable Region (HVR1) in the Immunogenicity of a Recombinant Hepatitis C Virus Vaccine. J. Virol. 2018, 92, e02141-17. [CrossRef] [PubMed]

102. McCaffrey, K.; Boo, I.; Owczarek, C.M.; Hardy, M.P.; Perugini, M.A.; Fabri, L.; Scotney, P.; Poumbourios, P.; Drummer, H.E. An Optimized Hepatitis C Virus E2 Glycoprotein Core Adopts a Functional Homodimer That Efficiently Blocks Virus Entry. J. Virol. 2017, 91, e01668-16. [CrossRef]

103. McCaffrey, K.; Boo, I.; Poumbourios, P.; Drummer, H.E. Expression and characterization of a minimal hepatitis $C$ virus glycoprotein E2 core domain that retains CD81 binding. J. Virol. 2007, 81, 9584-9590. [CrossRef]

104. Vietheer, P.T.; Boo, I.; Gu, J.; McCaffrey, K.; Edwards, S.; Owczarek, C.; Hardy, M.P.; Fabri, L.; Center, R.J.; Poumbourios, P.; et al. The core domain of hepatitis $\mathrm{C}$ virus glycoprotein $\mathrm{E} 2$ generates potent cross-neutralizing antibodies in guinea pigs. Hepatology 2017, 65, 1117-1131. [CrossRef]

105. He, L.; Tzarum, N.; Lin, X.; Shapero, B.; Sou, C.; Mann, C.J.; Stano, A.; Zhang, L.; Nagy, K.; Giang, E.; et al. Proof of concept for rational design of hepatitis $C$ virus $E 2$ core nanoparticle vaccines. Sci. Adv. 2020, 6, eaaz6225. [CrossRef] [PubMed]

106. Falkowska, E.; Kajumo, F.; Garcia, E.; Reinus, J.; Dragic, T. Hepatitis C virus envelope glycoprotein E2 glycans modulate entry, CD81 binding, and neutralization. J. Virol. 2007, 81, 8072-8079. [CrossRef]

107. Helle, F.; Goffard, A.; Morel, V.; Duverlie, G.; McKeating, J.; Keck, Z.Y.; Foung, S.; Penin, F.; Dubuisson, J.; Voisset, C. The neutralizing activity of anti-hepatitis $C$ virus antibodies is modulated by specific glycans on the E2 envelope protein. J. Virol. 2007, 81, 8101-8111. [CrossRef] [PubMed]

108. Pantua, H.; Diao, J.; Ultsch, M.; Hazen, M.; Mathieu, M.; McCutcheon, K.; Takeda, K.; Date, S.; Cheung, T.K.; Phung, Q.; et al. Glycan shifting on hepatitis C virus (HCV) E2 glycoprotein is a mechanism for escape from broadly neutralizing antibodies. J. Mol. Biol. 2013, 425, 1899-1914. [CrossRef]

109. Liu, M.; Chen, H.; Luo, F.; Li, P.; Pan, Q.; Xia, B.; Qi, Z.; Ho, W.Z.; Zhang, X.L. Deletion of N-glycosylation sites of hepatitis C virus envelope protein E1 enhances specific cellular and humoral immune responses. Vaccine 2007, 25, 6572-6580. [CrossRef]

110. Ren, Y.; Min, Y.Q.; Liu, M.; Chi, L.; Zhao, P.; Zhang, X.L. N-glycosylation-mutated HCV envelope glycoprotein complex enhances antigen-presenting activity and cellular and neutralizing antibody responses. Biochim. Biophys. Acta 2016, 1860, 1764-1775. [CrossRef]

111. Urbanowicz, R.A.; Wang, R.; Schiel, J.E.; Keck, Z.Y.; Kerzic, M.C.; Lau, P.; Rangarajan, S.; Garagusi, K.J.; Tan, L.; Guest, J.D.; et al. Antigenicity and Immunogenicity of Differentially Glycosylated Hepatitis C Virus E2 Envelope Proteins Expressed in Mammalian and Insect Cells. J. Virol. 2019, 93. [CrossRef] [PubMed]

112. Rao, X.; Hoof, I.; van Baarle, D.; Kesmir, C.; Textor, J. HLA Preferences for Conserved Epitopes: A Potential Mechanism for Hepatitis C Clearance. Front. Immunol. 2015, 6, 552. [CrossRef] [PubMed]

113. Andrianov, A.K.; Fuerst, T.R. Immunopotentiating and Delivery Systems for HCV Vaccines. Viruses 2021, 13, 981. [CrossRef] [PubMed]

114. Sepulveda-Crespo, D.; Resino, S.; Martinez, I. Innate Immune Response against Hepatitis C Virus: Targets for Vaccine Adjuvants. Vaccines 2020, 8, 313. [CrossRef]

115. Baden, L.R.; El Sahly, H.M.; Essink, B.; Kotloff, K.; Frey, S.; Novak, R.; Diemert, D.; Spector, S.A.; Rouphael, N.; Creech, C.B.; et al. Efficacy and Safety of the mRNA-1273 SARS-CoV-2 Vaccine. N. Engl. J. Med. 2021, 384, 403-416. [CrossRef] 
116. Polack, F.P.; Thomas, S.J.; Kitchin, N.; Absalon, J.; Gurtman, A.; Lockhart, S.; Perez, J.L.; Perez Marc, G.; Moreira, E.D.; Zerbini, C.; et al. Safety and Efficacy of the BNT162b2 mRNA Covid-19 Vaccine. N. Engl. J. Med. 2020, 383, 2603-2615. [CrossRef] [PubMed]

117. Vogel, A.B.; Kanevsky, I.; Che, Y.; Swanson, K.A.; Muik, A.; Vormehr, M.; Kranz, L.M.; Walzer, K.C.; Hein, S.; Guler, A.; et al. BNT162b vaccines protect rhesus macaques from SARS-CoV-2. Nature 2021, 592, 283-289. [CrossRef] [PubMed]

118. Corbett, K.S.; Edwards, D.K.; Leist, S.R.; Abiona, O.M.; Boyoglu-Barnum, S.; Gillespie, R.A.; Himansu, S.; Schafer, A.; Ziwawo, C.T.; DiPiazza, A.T.; et al. SARS-CoV-2 mRNA vaccine design enabled by prototype pathogen preparedness. Nature 2020, 586, 567-571. [CrossRef] [PubMed]

119. Sahin, U.; Muik, A.; Vogler, I.; Derhovanessian, E.; Kranz, L.M.; Vormehr, M.; Quandt, J.; Bidmon, N.; Ulges, A.; Baum, A.; et al. BNT162b2 vaccine induces neutralizing antibodies and poly-specific T cells in humans. Nature 2021. [CrossRef]

120. Corbett, K.S.; Flynn, B.; Foulds, K.E.; Francica, J.R.; Boyoglu-Barnum, S.; Werner, A.P.; Flach, B.; O'Connell, S.; Bock, K.W.; Minai, M.; et al. Evaluation of the mRNA-1273 Vaccine against SARS-CoV-2 in Nonhuman Primates. N. Engl. J. Med. 2020, 383, 1544-1555. [CrossRef]

121. Jackson, L.A.; Anderson, E.J.; Rouphael, N.G.; Roberts, P.C.; Makhene, M.; Coler, R.N.; McCullough, M.P.; Chappell, J.D.; Denison, M.R.; Stevens, L.J.; et al. An mRNA Vaccine against SARS-CoV-2-Preliminary Report. N. Engl. J. Med. 2020, 383, 1920-1931. [CrossRef]

122. Suryaprasad, A.G.; White, J.Z.; Xu, F.; Eichler, B.A.; Hamilton, J.; Patel, A.; Hamdounia, S.B.; Church, D.R.; Barton, K.; Fisher, C.; et al. Emerging epidemic of hepatitis $C$ virus infections among young nonurban persons who inject drugs in the United States, 2006-2012. Clin. Infect. Dis. Off. Publ. Infect. Dis. Soc. Am. 2014, 59, 1411-1419. [CrossRef]

123. Roy, S.; Ninkovic, J.; Banerjee, S.; Charboneau, R.G.; Das, S.; Dutta, R.; Kirchner, V.A.; Koodie, L.; Ma, J.; Meng, J.; et al. Opioid drug abuse and modulation of immune function: Consequences in the susceptibility to opportunistic infections. J. Neuroimmune Pharmacol. Off. J. Soc. NeuroImmune Pharmacol. 2011, 6, 442-465. [CrossRef]

124. Zhang, R.; Meng, J.; Lian, Q.; Chen, X.; Bauman, B.; Chu, H.; Segura, B.; Roy, S. Prescription opioids are associated with higher mortality in patients diagnosed with sepsis: A retrospective cohort study using electronic health records. PLoS ONE 2018, 13, e0190362. [CrossRef]

125. Kamath, G.R.; Shah, D.P.; Hwang, L.Y. Immune response to hepatitis B vaccination in drug using populations: A systematic review and meta-regression analysis. Vaccine 2014, 32, 2265-2274. [CrossRef] [PubMed]

126. Arora, P.K.; Fride, E.; Petitto, J.; Waggie, K.; Skolnick, P. Morphine-induced immune alterations in vivo. Cell. Immunol. 1990, 126, 343-353. [CrossRef]

127. Carr, D.J.; France, C.P. Immune alterations in morphine-treated rhesus monkeys. J. Pharmacol. Exp. Ther. 1993, $267,9-15$.

128. Cornwell, W.D.; Lewis, M.G.; Fan, X.; Rappaport, J.; Rogers, T.J. Effect of chronic morphine administration on circulating T cell population dynamics in rhesus macaques. J. Neuroimmunol. 2013, 265, 43-50. [CrossRef]

129. Mao, M.; Qian, Y.; Sun, J. Morphine Suppresses T helper Lymphocyte Differentiation to Th1 Type Through PI3K/AKT Pathway. Inflammation 2016, 39, 813-821. [CrossRef]

130. Roy, S.; Balasubramanian, S.; Sumandeep, S.; Charboneau, R.; Wang, J.; Melnyk, D.; Beilman, G.J.; Vatassery, R.; Barke, R.A. Morphine directs T cells toward T(H2) differentiation. Surgery 2001, 130, 304-309. [CrossRef]

131. Roy, S.; Wang, J.; Gupta, S.; Charboneau, R.; Loh, H.H.; Barke, R.A. Chronic morphine treatment differentiates T helper cells to Th2 effector cells by modulating transcription factors GATA 3 and T-bet. J. Neuroimmunol. 2004, 147, 78-81. [CrossRef]

132. Zhang, E.Y.; Xiong, J.; Parker, B.L.; Chen, A.Y.; Fields, P.E.; Ma, X.; Qiu, J.; Yankee, T.M. Depletion and recovery of lymphoid subsets following morphine administration. Br. J. Pharmacol. 2011, 164, 1829-1844. [CrossRef] [PubMed]

133. Kumar, R.; Orsoni, S.; Norman, L.; Verma, A.S.; Tirado, G.; Giavedoni, L.D.; Staprans, S.; Miller, G.M.; Buch, S.J.; Kumar, A. Chronic morphine exposure causes pronounced virus replication in cerebral compartment and accelerated onset of AIDS in SIV/SHIV-infected Indian rhesus macaques. Virology 2006, 354, 192-206. [CrossRef] [PubMed]

134. Eisenstein, T.K. The Role of Opioid Receptors in Immune System Function. Front. Immunol. 2019, 10, 2904. [CrossRef] [PubMed]

135. Brejchova, J.; Holan, V.; Svoboda, P. Expression of Opioid Receptors in Cells of the Immune System. Int. J. Mol. Sci. 2020, 22, 315. [CrossRef]

136. Karagiannis, T.T.; Cleary, J.P., Jr.; Gok, B.; Henderson, A.J.; Martin, N.G.; Yajima, M.; Nelson, E.C.; Cheng, C.S. Single cell transcriptomics reveals opioid usage evokes widespread suppression of antiviral gene program. Nat. Commun. 2020, $11,2611$. [CrossRef]

137. Wang, X.; Zhang, T.; Ho, W.Z. Opioids and HIV/HCV infection. J. Neuroimmune Pharmacol. Off. J. Soc. NeuroImmune Pharmacol. 2011, 6, 477-489. [CrossRef]

138. Deren, S.; Cleland, C.M.; Lee, H.; Mehandru, S.; Markowitz, M. Brief Report: The Relationship Between Injection Drug Use Risk Behaviors and Markers of Immune Activation. J. Acquir. Immune Defic. Syndr. 2017, 75, e8-e12. [CrossRef]

139. Tomescu, C.; Colon, K.; Smith, P.; Taylor, M.; Azzoni, L.; Metzger, D.S.; Montaner, L.J. Persons who inject drugs (PWID) retain functional NK cells, dendritic cell stimulation, and adaptive immune recall responses despite prolonged opioid use. J. Leukoc. Biol. 2020. [CrossRef]

140. Baral, S.; Sherman, S.G.; Millson, P.; Beyrer, C. Vaccine immunogenicity in injecting drug users: A systematic review. Lancet Infect. Dis. 2007, 7, 667-674. [CrossRef] 
141. Feng, Y.; Shi, J.; Gao, L.; Yao, T.; Feng, D.; Luo, D.; Li, Z.; Zhang, Y.; Wang, F.; Cui, F.; et al. Immunogenicity and safety of high-dose hepatitis B vaccine among drug users: A randomized, open-labeled, blank-controlled trial. Hum. Vaccine Immunother. 2017, 13, 1-7. [CrossRef] [PubMed]

142. Moroz, E.; Albrecht, R.A.; Aden, B.; Beeder, A.B.; Yuan, J.; García-Sastre, A.; Edlin, B.R.; Salvatore, M. Active opioid use does not attenuate the humoral responses to inactivated influenza vaccine. Vaccine 2016, 34, 1363-1369. [CrossRef] [PubMed]

143. Freeman, A.J.; Ffrench, R.A.; Post, J.J.; Harvey, C.E.; Gilmour, S.J.; White, P.A.; Marinos, G.; van Beek, I.; Rawlinson, W.D.; Lloyd, A.R. Prevalence of production of virus-specific interferon-gamma among seronegative hepatitis C-resistant subjects reporting injection drug use. J. Infect. Dis. 2004, 190, 1093-1097. [CrossRef] [PubMed]

144. Mizukoshi, E.; Eisenbach, C.; Edlin, B.R.; Newton, K.P.; Raghuraman, S.; Weiler-Normann, C.; Tobler, L.H.; Busch, M.P.; Carrington, M.; McKeating, J.A.; et al. Hepatitis C virus (HCV)-specific immune responses of long-term injection drug users frequently exposed to HCV. J. Infect. Dis. 2008, 198, 203-212. [CrossRef]

145. Thurairajah, P.H.; Hegazy, D.; Chokshi, S.; Shaw, S.; Demaine, A.; Kaminski, E.R.; Naoumov, N.V.; Cramp, M.E. Hepatitis C virus (HCV)-specific T cell responses in injection drug users with apparent resistance to HCV infection. J. Infect. Dis. 2008, 198, 1749-1755. [CrossRef] [PubMed]

146. Abdelwahab, S.F.; Zakaria, Z.; Sobhy, M.; Rewisha, E.; Mahmoud, M.A.; Amer, M.A.; Del Sorbo, M.; Capone, S.; Nicosia, A.; Folgori, A.; et al. Hepatitis C virus-multispecific T-cell responses without viremia or seroconversion among Egyptian health care workers at high risk of infection. Clin. Vaccine Immunol. 2012, 19, 780-786. [CrossRef]

147. Heller, T.; Werner, J.M.; Rahman, F.; Mizukoshi, E.; Sobao, Y.; Gordon, A.M.; Sheets, A.; Sherker, A.H.; Kessler, E.; Bean, K.S.; et al. Occupational exposure to hepatitis $\mathrm{C}$ virus: Early T-cell responses in the absence of seroconversion in a longitudinal cohort study. J. Infect. Dis. 2013, 208, 1020-1025. [CrossRef]

148. Kubitschke, A.; Bahr, M.J.; Aslan, N.; Bader, C.; Tillmann, H.L.; Sarrazin, C.; Greten, T.; Wiegand, J.; Manns, M.P.; Wedemeyer, H. Induction of hepatitis $\mathrm{C}$ virus (HCV)-specific T cells by needle stick injury in the absence of HCV-viraemia. Eur. J. Clin. Investig. 2007, 37, 54-64. [CrossRef] [PubMed]

149. Perrella, A.; Grattacaso, S.; d'Antonio, A.; Atripaldi, L.; Sbreglia, C.; Gnarini, M.; Conti, P.; Vecchiet, J.; Perrella, O. Evidence of hepatitis $\mathrm{C}$ virus-specific interferon gamma-positive T cells in health care workers in an infectious disease department. Am. J. Infect. Control 2009, 37, 426-429. [CrossRef] [PubMed]

150. Al-Sherbiny, M.; Osman, A.; Mohamed, N.; Shata, M.T.; Abdel-Aziz, F.; Abdel-Hamid, M.; Abdelwahab, S.F.; Mikhail, N.; Stoszek, S.; Ruggeri, L.; et al. Exposure to hepatitis $C$ virus induces cellular immune responses without detectable viremia or seroconversion. Am. J. Trop. Med. Hyg. 2005, 73, 44-49. [CrossRef] [PubMed]

151. Hashem, M.; El-Karaksy, H.; Shata, M.T.; Sobhy, M.; Helmy, H.; El-Naghi, S.; Galal, G.; Ali, Z.Z.; Esmat, G.; Abdelwahab, S.F.; et al. Strong hepatitis $\mathrm{C}$ virus (HCV)-specific cell-mediated immune responses in the absence of viremia or antibodies among uninfected siblings of HCV chronically infected children. J. Infect. Dis. 2011, 203, 854-861. [CrossRef]

152. Scognamiglio, P.; Accapezzato, D.; Casciaro, M.A.; Cacciani, A.; Artini, M.; Bruno, G.; Chircu, M.L.; Sidney, J.; Southwood, S.; Abrignani, S.; et al. Presence of effector CD8+ T cells in hepatitis C virus-exposed healthy seronegative donors. J. Immunol. 1999, 162, 6681-6689.

153. Kamal, S.M.; Amin, A.; Madwar, M.; Graham, C.S.; He, Q.; Al Tawil, A.; Rasenack, J.; Nakano, T.; Robertson, B.; Ismail, A.; et al. Cellular immune responses in seronegative sexual contacts of acute hepatitis C patients. J. Virol. 2004, 78, 12252-12258. [CrossRef]

154. Takaki, A.; Wiese, M.; Maertens, G.; Depla, E.; Seifert, U.; Liebetrau, A.; Miller, J.L.; Manns, M.P.; Rehermann, B. Cellular immune responses persist and humoral responses decrease two decades after recovery from a single-source outbreak of hepatitis $\mathrm{C}$. Nat. Med. 2000, 6, 578-582. [CrossRef]

155. Park, S.H.; Veerapu, N.S.; Shin, E.C.; Biancotto, A.; McCoy, J.P.; Capone, S.; Folgori, A.; Rehermann, B. Subinfectious hepatitis C virus exposures suppress T cell responses against subsequent acute infection. Nat. Med. 2013, 19, 1638-1642. [CrossRef]

156. Esposito, I.; Cicconi, P.; D’Alise, A.M.; Brown, A.; Esposito, M.; Swadling, L.; Holst, P.J.; Bassi, M.R.; Stornaiuolo, M.; Mori, F.; et al. MHC class II invariant chain-adjuvanted viral vectored vaccines enhances T cell responses in humans. Sci. Transl. Med. 2020, 12. [CrossRef] [PubMed]

157. Midgard, H.; Bjøro, B.; Mæland, A.; Konopski, Z.; Kileng, H.; Damås, J.K.; Paulsen, J.; Heggelund, L.; Sandvei, P.K.; Ringstad, J.O.; et al. Hepatitis C reinfection after sustained virological response. J. Hepatol. 2016, 64, 1020-1026. [CrossRef] [PubMed]

158. Rossi, C.; Butt, Z.A.; Wong, S.; Buxton, J.A.; Islam, N.; Yu, A.; Darvishian, M.; Gilbert, M.; Wong, J.; Chapinal, N.; et al. Hepatitis C virus reinfection after successful treatment with direct-acting antiviral therapy in a large population-based cohort. J. Hepatol. 2018, 69, 1007-1014. [CrossRef]

159. Akiyama, M.J.; Lipsey, D.; Heo, M.; Agyemang, L.; Norton, B.L.; Hidalgo, J.; Lora, K.; Litwin, A.H. Low Hepatitis C Reinfection Following Direct-acting Antiviral Therapy Among People Who Inject Drugs on Opioid Agonist Therapy. Clin. Infect. Dis. Off. Publ. Infect. Dis. Soc. Am. 2020, 70, 2695-2702. [CrossRef]

160. Chang, K.M.; Thimme, R.; Melpolder, J.J.; Oldach, D.; Pemberton, J.; Moorhead-Loudis, J.; McHutchison, J.G.; Alter, H.J.; Chisari, F.V. Differential CD4(+) and CD8(+) T-cell responsiveness in hepatitis C virus infection. Hepatology 2001, 33, 267-276. [CrossRef]

161. Day, C.L.; Lauer, G.M.; Robbins, G.K.; McGovern, B.; Wurcel, A.G.; Gandhi, R.T.; Chung, R.T.; Walker, B.D. Broad specificity of virus-specific CD4+ T-helper-cell responses in resolved hepatitis C virus infection. J. Virol. 2002, 76, 12584-12595. [CrossRef] [PubMed] 
162. Gerlach, J.T.; Diepolder, H.M.; Jung, M.C.; Gruener, N.H.; Schraut, W.W.; Zachoval, R.; Hoffmann, R.; Schirren, C.A.; Santantonio, T.; Pape, G.R. Recurrence of hepatitis C virus after loss of virus-specific CD4(+) T-cell response in acute hepatitis C. Gastroenterology 1999, 117, 933-941. [CrossRef]

163. Radziewicz, H.; Ibegbu, C.C.; Fernandez, M.L.; Workowski, K.A.; Obideen, K.; Wehbi, M.; Hanson, H.L.; Steinberg, J.P.; Masopust, D.; Wherry, E.J.; et al. Liver-infiltrating lymphocytes in chronic human hepatitis $\mathrm{C}$ virus infection display an exhausted phenotype with high levels of PD-1 and low levels of CD127 expression. J. Virol. 2007, 81, 2545-2553. [CrossRef]

164. Nitschke, K.; Flecken, T.; Schmidt, J.; Gostick, E.; Marget, M.; Neumann-Haefelin, C.; Blum, H.E.; Price, D.A.; Thimme, R. Tetramer enrichment reveals the presence of phenotypically diverse hepatitis C virus-specific CD8+ T cells in chronic infection. J. Virol. 2015, 89, 25-34. [CrossRef] [PubMed]

165. Urbani, S.; Amadei, B.; Tola, D.; Massari, M.; Schivazappa, S.; Missale, G.; Ferrari, C. PD-1 expression in acute hepatitis C virus (HCV) infection is associated with HCV-specific CD8 exhaustion. J. Virol. 2006, 80, 11398-11403. [CrossRef] [PubMed]

166. Cox, A.L.; Mosbruger, T.; Lauer, G.M.; Pardoll, D.; Thomas, D.L.; Ray, S.C. Comprehensive analyses of CD8+ T cell responses during longitudinal study of acute human hepatitis C. Hepatology 2005, 42, 104-112. [CrossRef]

167. Cox, A.L.; Mosbruger, T.; Mao, Q.; Liu, Z.; Wang, X.H.; Yang, H.C.; Sidney, J.; Sette, A.; Pardoll, D.; Thomas, D.L.; et al. Cellular immune selection with hepatitis $C$ virus persistence in humans. J. Exp. Med. 2005, 201, 1741-1752. [CrossRef]

168. Erickson, A.L.; Kimura, Y.; Igarashi, S.; Eichelberger, J.; Houghton, M.; Sidney, J.; McKinney, D.; Sette, A.; Hughes, A.L.; Walker, C.M. The outcome of hepatitis $\mathrm{C}$ virus infection is predicted by escape mutations in epitopes targeted by cytotoxic $\mathrm{T}$ lymphocytes. Immunity 2001, 15, 883-895. [CrossRef]

169. Neumann-Haefelin, C.; Timm, J.; Spangenberg, H.C.; Wischniowski, N.; Nazarova, N.; Kersting, N.; Roggendorf, M.; Allen, T.M.; Blum, H.E.; Thimme, R. Virological and immunological determinants of intrahepatic virus-specific CD8+ T-cell failure in chronic hepatitis C virus infection. Hepatology 2008, 47, 1824-1836. [CrossRef]

170. Martin, B.; Hennecke, N.; Lohmann, V.; Kayser, A.; Neumann-Haefelin, C.; Kukolj, G.; Böcher, W.O.; Thimme, R. Restoration of HCV-specific CD8+ T cell function by interferon-free therapy. J. Hepatol. 2014, 61, 538-543. [CrossRef]

171. Han, J.W.; Sung, P.S.; Kim, K.H.; Hong, S.H.; Shin, E.C.; Jun Song, M.; Park, S.H. Dynamic Changes in Ex Vivo T-Cell Function After Viral Clearance in Chronic HCV Infection. J. Infect. Dis. 2019, 220, 1290-1301. [CrossRef] [PubMed]

172. Callendret, B.; Eccleston, H.B.; Hall, S.; Satterfield, W.; Capone, S.; Folgori, A.; Cortese, R.; Nicosia, A.; Walker, C.M. T-cell immunity and hepatitis $C$ virus reinfection after cure of chronic hepatitis $C$ with an interferon-free antiviral regimen in a chimpanzee. Hepatology 2014, 60, 1531-1540. [CrossRef]

173. Wieland, D.; Kemming, J.; Schuch, A.; Emmerich, F.; Knolle, P.; Neumann-Haefelin, C.; Held, W.; Zehn, D.; Hofmann, M.; Thimme, R. TCF1(+) hepatitis C virus-specific CD8(+) T cells are maintained after cessation of chronic antigen stimulation. Nat. Commun. 2017, 8, 15050. [CrossRef]

174. Hensel, N.; Gu, Z.; Sagar; Wieland, D.; Jechow, K.; Kemming, J.; Llewellyn-Lacey, S.; Gostick, E.; Sogukpinar, O.; Emmerich, F.; et al. Memory-like HCV-specific CD8(+) T cells retain a molecular scar after cure of chronic HCV infection. Nat. Immunol. 2021, 22, 229-239. [CrossRef]

175. Aregay, A.; Owusu Sekyere, S.; Deterding, K.; Port, K.; Dietz, J.; Berkowski, C.; Sarrazin, C.; Manns, M.P.; Cornberg, M.; Wedemeyer, $\mathrm{H}$. Elimination of hepatitis $\mathrm{C}$ virus has limited impact on the functional and mitochondrial impairment of HCVspecific CD8+ T cell responses. J. Hepatol. 2019, 71, 889-899. [CrossRef] [PubMed]

176. Barili, V.; Fisicaro, P.; Montanini, B.; Acerbi, G.; Filippi, A.; Forleo, G.; Romualdi, C.; Ferracin, M.; Guerrieri, F.; Pedrazzi, G.; et al. Targeting p53 and histone methyltransferases restores exhausted CD8+ T cells in HCV infection. Nat. Commun. 2020, 11, 604. [CrossRef]

177. Wolski, D.; Foote, P.K.; Chen, D.Y.; Lewis-Ximenez, L.L.; Fauvelle, C.; Aneja, J.; Walker, A.; Tonnerre, P.; Torres-Cornejo, A.; Kvistad, D.; et al. Early Transcriptional Divergence Marks Virus-Specific Primary Human CD8(+) T Cells in Chronic versus Acute Infection. Immunity 2017, 47, 648-663.e8. [CrossRef] [PubMed]

178. Alfei, F.; Kanev, K.; Hofmann, M.; Wu, M.; Ghoneim, H.E.; Roelli, P.; Utzschneider, D.T.; von Hoesslin, M.; Cullen, J.G.; Fan, Y.; et al. TOX reinforces the phenotype and longevity of exhausted T cells in chronic viral infection. Nature 2019, 571, 265-269. [CrossRef] [PubMed]

179. Smits, M.; Zoldan, K.; Ishaque, N.; Gu, Z.; Jechow, K.; Wieland, D.; Conrad, C.; Eils, R.; Fauvelle, C.; Baumert, T.F.; et al. Follicular T helper cells shape the HCV-specific CD4+ T cell repertoire after virus elimination. J. Clin. Investig. 2020, 130, 998-1009. [CrossRef]

180. Khanam, A.; Kottilil, S.; Wilson, E. Reconstitution of T follicular helper-humoral immune axis with elimination of hepatitis C virus. Sci. Rep. 2020, 10, 19924. [CrossRef]

181. Hartnell, F.; Esposito, I.; Swadling, L.; Brown, A.; Phetsouphanh, C.; de Lara, C.; Gentile, C.; Turner, B.; Kopycinski, J.; Dorrell, L.; et al. Characterising HCV specific CD4+ T-cells following viral-vectored vaccination, directly acting anti-virals and spontaneous viral cure. Hepatology 2020. [CrossRef] [PubMed]

182. Sipeki, N.; Antal-Szalmas, P.; Lakatos, P.L.; Papp, M. Immune dysfunction in cirrhosis. World J. Gastroenterol. 2014, 20 , $2564-2577$. [CrossRef] 
183. Verna, E.C.; Morelli, G.; Terrault, N.A.; Lok, A.S.; Lim, J.K.; Di Bisceglie, A.M.; Zeuzem, S.; Landis, C.S.; Kwo, P.; Hassan, M.; et al. DAA therapy and long-term hepatic function in advanced/decompensated cirrhosis: Real-world experience from HCV-TARGET cohort. J. Hepatol. 2020, 73, 540-548. [CrossRef]

184. Vranjkovic, A.; Deonarine, F.; Kaka, S.; Angel, J.B.; Cooper, C.L.; Crawley, A.M. Direct-Acting Antiviral Treatment of HCV Infection Does Not Resolve the Dysfunction of Circulating CD8(+) T-Cells in Advanced Liver Disease. Front. Immunol. 2019, 10, 1926. [CrossRef] [PubMed]

185. Cheong, H.J.; Song, J.Y.; Park, J.W.; Yeon, J.E.; Byun, K.S.; Lee, C.H.; Cho, H.I.; Kim, T.G.; Kim, W.J. Humoral and cellular immune responses to influenza vaccine in patients with advanced cirrhosis. Vaccine 2006, 24, 2417-2422. [CrossRef] [PubMed]

186. Kim, K.H.; Roberts, C.W. Targeting EZH2 in cancer. Nat. Med. 2016, 22, 128-134. [CrossRef] [PubMed] 